\title{
Eesti keele kui teise keele kirjutamisprotsessi paranduste multidimensionaalne võrdlus keeleoskustasemeti
}

OLGA PASTUHHOVA

Tallinna Ülikool

Ülevaade. Artikli eesmärk on kirjeldada venekeelsete eesti keele óppijate kirjutamisprotsessi parandusi ja nende seost "Euroopa keeleõppe raamdokumendi" A2-, B1-, B2- ja C1- keeleoskustasemega, lähtudes multidimensionaalsest (Stevenson jt 2006) ning Eva Lindgreni ja Kirk P. H. Sullivani (2006b) taksonoomiast. Uurimuses osales 34 üliópilast. Materjal on kogutud klaviatuuri klahvivajutuste salvestuse meetodil põhineva ScriptLog-programmiga. Kirjutamisprotsessi jooksul tehtud parandusi on analüüsitud vastavalt paranduse tegevusele (asendused ja lisandumised), liigile (trükivead, vormi- ja kontseptuaalsed parandused), tekstis esinemise asukohale (kontekstieelsed ja kontekstisidusad parandused) ning paranduse valdkonnale (sõna, lause või pikema teksti tasand). Paranduste jaotust võrreldakse keeleoskustasemeti.

Võtmesõnad: teise keele omandamine; kirjutamisoskus; klaviatuuri klahvivajutuste salvestuse meetod; ScriptLog; multidimensionaalne taksonoomia; LS-taksonoomia; eesti keel; vene keel 


\section{Sissejuhatus}

Teksti parandamine on kirjutamisprotsessi lahutamatu osa. Paranduste uurimist käsitlevates artiklites on laialt levinud Jill Fitzgeraldi (1987: 484) määratlus, mille kohaselt on parandus (ingl revision) mistahes muudatus kirjutamisprotsessi (kas tekstis või protsessi käigus) suvalisel hetkel. Esiteks hõlmab see soovitud ja kirjutatud teksti erinevuste kindlaks tegemist, teiseks otsustamist, mida võiks või tuleks tekstis muuta, ja kolmandaks, kuidas soovitud muudatusi sisse viia. Määratluse järgi parandused võivad, aga ei pruugi teksti mõjutada ning võivad olla kas suured või väikesed.

Teksti parandamist üldisemalt ja eriti vigade parandamist, mida on võimalik uurida nii valmis tekstis kui ka teksti produtseerimise ajal, peetakse kognitiivselt keeruliseks ülesandeks (Leijten jt 2010: 194). Klaviatuuri klahvivajutuste salvestuse meetodiga kogutud uurimismaterjal näitab uurijale keeleloome kognitiivseid aspekte. Näiteks, uurides kirjutaja liikumist tekstis, on võimalik jälgida, millele kirjutaja keskendab oma tähelepanu teksti produtseerimise ajal, kuidas ja mis järjestuses nihutab ta fookust ehk millist teekonda ta läbib keeleloome käigus. Samuti kajastavad tehtud parandused kognitiivseid raskusi, mida kirjutaja teksti produtseerimisel kogeb, ning nende lahendamise viise.

Teksti parandamine on kirjeldatav John R. Hayes'i ja Linda S. Floweri (1980; Flower \& Hayes 1981; Hayes jt 1987; Chenoweth \& Hayes 2001; Hayes 2012) kirjutamisprotsessi mudeli abil. Mudel kajastab parandamise olemust, toimimist ja parandamisse kaasatud kognitiivseid protsesse. Samuti on võimalik kirjutamisprotsessi analüüsida paranduste uurimise metodoloogiliseks abivahendiks loodud paranduste taksonoomiatest lähtudes. Kirjutamisprotsessi mudelid näitavad paranduste tekkimise põhjusi, taksonoomiad kajastavad paranduste mõju tekstile. Käesolev artikkel annab kirjutamisprotsessi parandamise ülevaate kirjutamismudeli seisukohast ning keskendub venekeelsete eesti keele õppijate parandustele taksonoomiatest lähtudes. Kui varasemad uurimused käsitlevad emakeeles ja teises keeles kirjutamise protsessi ja selle käigus 
tehtud paranduste võrdlust, siis siinses artiklis käsitletav uurimus seab eesmärgiks kirjeldada teises keeles kirjutamise protsessi parandusi ning nende muutust keeleoskustasemeti. Kirjutamisprotsessi paranduste uurimine võimaldab heita valgust keeleloome kognitiivsetele raskustele ja nende lahendamisele, mis on oluline keele omandamise ja õpetamise seisukohast.

Uuringus osales 34 venekeelset Tallinna Ülikooli üliõpilast, kellel paluti kirjutada arvutis loovkirjutis haridusega seotud teemal. Valmis tekste hindas kaks eksperti, kelle hinnangul vastasid loovkirjutised antud ülesande järgi "Euroopa keeleõppe raamdokumendi" algtasemel keelekasutaja esmase keeleoskuse A2-, iseseisva keelekasutaja suhtlusläve B1- ja edasijõudnu B2- ning vilunud keelekasutaja vaba suhtluse pädevuse C1-tasemele. Materjal on kogutud klaviatuuri klahvivajutuste salvestuse meetodiga, mis võimaldab kogu kirjutamisprotsessi jooksul tehtud paranduste uurimist. Paranduste uurimise aluseks on peamiselt Marie Stevensoni jt (2006) multidimensionaalne taksonoomia, kuid kontekstieelsete ja kontekstisidusate paranduste analüüsimisel kasutatakse Lindgreni ja Sullivani (2006b) taksonoomiat (edaspidi LS-taksonoomia). Artiklis vaadeldakse, millele on osalejate tähelepanu suunatud teksti parandamisel, mis tüüpi parandused on sagedasemad ning kuidas muutub paranduste osakaal keeleoskustasemeti. Paranduse tegevuse osas eristatakse artiklis kustutamisjärgseid asendusi ja lisandumisi, paranduse liigi järgi eristatakse trükivigu, vormi- ja kontseptuaalseid parandusi, paranduse asukoha järgi tehakse vahet mõtte väljendamise hetkel tehtud kontekstieelsete ja varasemasse teksti tehtud kontekstisidusate paranduste vahel, paranduse valdkonna osas eristatakse parandusi sõna, lause või pikema teksti tasandil. 


\section{Parandamisprotsessi määratlus kirjutamismudeli seisukohast}

Kõige mõjukamad kirjutamisprotsessi mudelid said alguse 1980. aastatel kognitiivsest psühholoogiast ning Hayes ja Flower on sellel alal kõige rohkem tsiteeritud uurijad (Baaijen 2012: 20). Kirjutamist vaadeldi probleemi lahendamise ülesandena ning jagati alamprotsessideks eesmärgiga mõista kirjutamisprotsessi kui alamprotsesside vastastikust toimet (Hayes \& Flower 1980: 3; Hayes 2012: 375). Järgnevalt antakse lühiülevaade kirjutamismudeli edasiarendusest rõhuga parandamisel protsessi osana.

Hayes’i ja Floweri (1980) mudeli järgi koosneb kirjutamine kolmest põhilisest tegevusest: planeerimisest, tõlkimisest (s.o plaanide tõlkimisest tekstiks) ja ülevaatamisest (ingl reviewing). Ülevaatamise protsessi eesmärk on tõlkimise protsessi käigus produtseeritud teksti kvaliteedi parandamine, mis realiseerub lugemise ja toimetamise (ingl editing) alamprotsessis. Toimetamise eesmärk on määratleda ja parandada keelevigu ja sisu ebatäpsusi ning hinnata produtseeritud teksti vastavust kirjutamisülesande eesmärgile ja planeerimise ajal tehtud kavatsustele. Mudeli loojad eeldasid, et toimetamine on produtseerimissüsteem (järjestatud tingimuse ja tegevuse järgnevus) ning reageerib automaatselt õigekirjavigadele, faktilistele ebatäpsustele ja ebaselgusele, katkestades kõik muud protsessid avastatud probleemi lahendamiseks ehk vea parandamiseks. Kui toimetamine on automaatne protsess, mis esineb lühiajaliselt ja teisi protsesse katkestades, siis ülevaatamine on tegevus, kui kirjutaja otsustab pühendada teatud aja produtseeritud teksti süstemaatilisele uurimisele ja parandamisele. Ülevaatamine ei katkesta kirjutamist, vaid esineb siis, kui kirjutaja on lõpetanud tõlkimise protsessi. Kirjutamismudel on rekursiivne ning toimetama võib hakata kirjutamisprotsessi suvalisel hetkel. Kui toimetamine on käivitatud, siis planeerimisest, tõlkimisest ning ülevaatamisest koosnev kirjutamismudel võib esineda toimetamise osana. (Hayes \& Flower 1980: 11-29) 
1981. aasta mudelis on Flower ja Hayes (1981) oma teoreetilist seisukohta veidi muutnud. Siin eristavad nad ülevaatamise protsessi kaht alamprotsessi: hindamise (ingl evaluation) alamprotsess (lugemine ja produtseeritud teksti võrdlemine mõeldud tekstiga, vastab eelneva mudeli lugemise alamprotsessile) ning parandamise (ingl revision) alamprotsess (avastatud vigade parandus, vastab eelneva mudeli toimetamise alamprotsessile). Erinevalt 1980. aasta mudelist on parandamine siin tahtlik tegevus. Niisiis, erinevalt eelnevast mudelist peetakse ülevaatamise protsessi ning selle kaht alamprotsessi kontrollitud tegevuseks. Parandamise alamprotsess ei ole enam piiratud automaatse tegevusega, mis toimib vastavalt produtseerimise reeglitele. (Alamargot \& Chanquoy 2001: 103; Flower \& Hayes 1981: 374)

1983. aastal eristavad Hayes ja Flower ülevaatamise (ingl reviewing) tegevust ja parandamise tegevust (ingl revising). Ülevaatamist peetakse mentaalseks (või sisemiseks) tegevuseks, mis on vajalik produtseeritud teksti või plaanide hindamiseks ning mis võib viia lahknevuste tuvastamiseni mõeldud ja produtseeritud teksti vahel. Parandamist aga peetakse väliseks tegevuseks, mis viib teksti pindstruktuuri muudatusteni. (Alamargot \& Chanquoy 2001: 103)

Hayes jt (1987) on välja töötanud kognitiivseid protsesse kirjeldava väga täpse parandamise mudeli (ingl revision model), mida võib pidada keskseks raamistikuks vastavate mudelite seas. Mudel kirjeldab parandamise (ingl revising) protsesse, strateegiaid ja - mis on uus - vajalikke teadmisi parandamiseks. Nende uurijate arvates on parandamine (ingl revision) ennekõike tahtlik ja strateegiline tegevus. (Alamargot \& Chanquoy 2001: 106) Mudel koosneb ülesande määratluse, hindamise ning strateegia valiku alamprotsessist. Ülesande määratlus täpsustab kirjutaja parandamise eesmärki (grammatiline korrektsus, selgus või stiil), ulatust (lokaalne või globaalne) ning kasutatavat protseduuri. Hindamise etapp eristab lugemise kolme liiki: lugemine arusaamiseks, lugemine hindamiseks ja lugemine probleemi määratlemiseks. Kui probleem on määratletud, siis valitakse strateegia probleemi lahendamiseks. Eristatakse kahte liiki strateegiaid: 1) need, mis muudavad või kontrollivad 
parandamise protsessi: probleemi ignoreerimine, tegevuse edasilükkamine, ulatuslikuma informatsiooni otsimine probleemi selgitamiseks; 2) need, mis muudavad teksti: teksti parandamine või teksti ümberkirjutamine. (Hayes jt 1987: 185-188; Hayes 2004: 12-14)

Hayes'i ja Floweri mudeli (1980) täiustatud versioonis teeb Hayes (1996) vähem selget vahet kirjutamisprotsessi erinevate komponentide vahel. Kirjutamise kognitiivsed protsessid (planeerimine, tõlkimine, ülevaatamine) on ümber kujundatud refleksiooni, teksti produtseerimise ja teksti tõlgenduse kategooriateks. Lisaks ei ole parandamine enam kirjutamisprotsessist eraldi seisev protsess, vaid hõlmab refleksiooni, teksti produtseerimise ja teksti tõlgenduse tsükli rekursiivset rakendust. (Hayes 1996: 4-17)

N. Ann Chenoweth'i ja Hayes'i (2001) mudelis ning Hayes'i (2012) hilisemas mudelis on kirjutamisprotsess jagatud kolmeks tasandiks: kontrollitasand, kirjutamisprotsessi tasand ja ressursside tasand. Kirjutamisprotsessi tasandi sisemised protsessid sisaldavad ettepaneku tegemise (ingl proposer), tõlkimise (ingl translator), transkribeerimise (ingl transcriber) ja hindamise (ingl evaluator) komponenti ning ei sisalda enam parandamist. Kirjutatud teksti parandamist vaadeldakse kui spetsialiseeritud kirjutamistegevust. Parandamist alustatakse tekstis esineva probleemi määratlusega, mis sisaldab lahenduse planeerimist (kas kirjalikult või mitte), selle lahenduse tõlkimist keeleks ning keele transkribeerimist uueks tekstiks vana teksti asendamiseks. Sellest vaatevinklist ei ole parandamine eraldi kirjutamisprotsess, vaid kirjutamismudeli rakendus. (Hayes 2012: 375-376; Chenoweth \& Hayes 2001: 84)

Hayes'i mudeli edasiarendus näitab kirjutamisprotsessi puudutava arusaama arengut, kusjuures parandamise käsitlust on peetud keeruliseks ning mitmest alamprotsessist koosnevaks protsessiks. Iga uue mudeliga on parandamine muudetud detailsemaks ning alamprotsessid on üksikasjalikumalt määratletud. Kui esialgu nähti parandamist omaette protsessina, siis hilisemas versioonis jõuti arusaamale, et teksti parandamine on käsitletav kogu kirjutamisprotsessina. Hayes'i mudel on leidnud rohket käsitlust kirjutamise uurimustes (nt Alamargot \& 
Chanquoy 2001; Becker 2006; Spelman Miller jt 2008; Galbraith 2009; Baaijen 2012; Breuer 2014; Khuder \& Harwood 2015; Gustilo \& Magno 2015).

\section{Paranduste taksonoomiad}

Teine lähenemine parandamisprotsessile on liigitada vastavalt kindlatele kriteeriumidele paranduste (ingl revision) tüüpe, mis tekstis esinevad (Alamargot \& Chanquoy 2001: 100). Joonis 1 kirjeldab Lindgreni ja Sullivani (2006a) koostöös Stevensoni ja kolleegidega (Stevenson jt 2006) välja töötatud paranduste jaotust vastavalt tüübile ja tekstis esinemise asukohale (Lindgren \& Sullivan 2006a: 37-39).

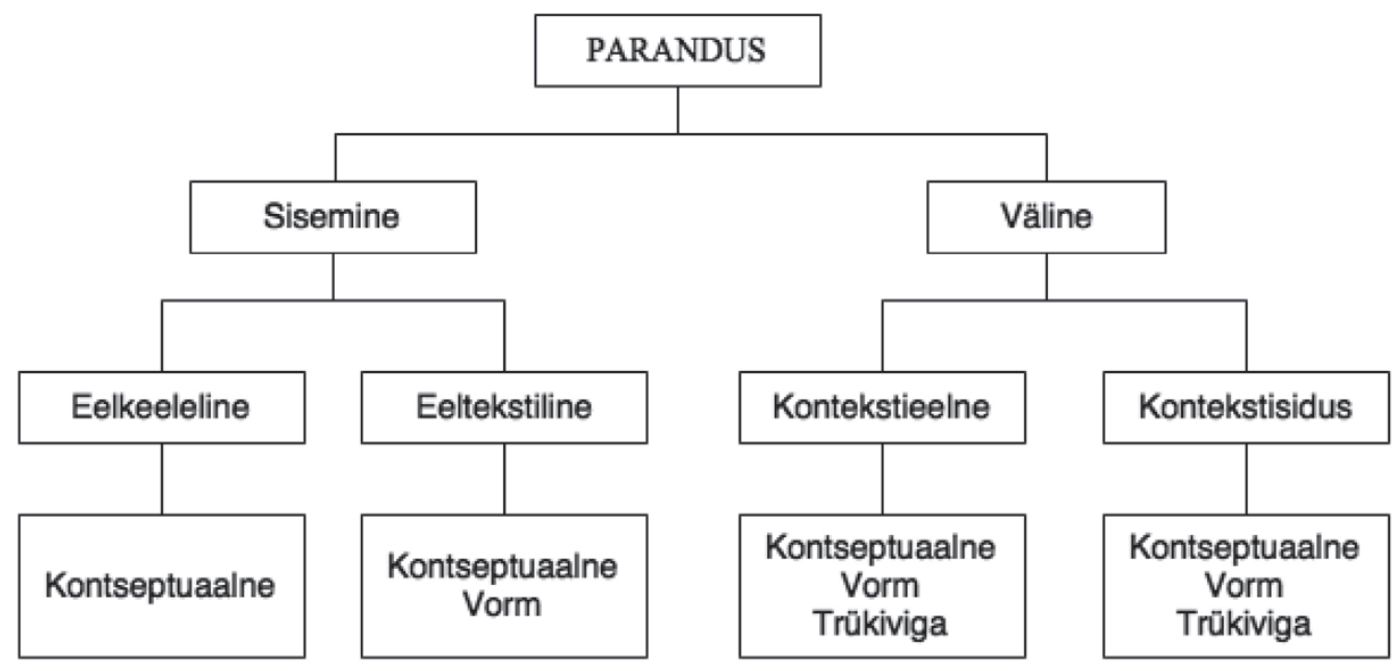

Joonis 1. Paranduste jaotus vastavalt tü̈̈bile ja asukohale (Lindgren \& Sullivan 2006a: 39)

Kõigepealt jagatakse parandused sisemisteks ja välisteks. Sisemised parandused esinevad mentaalselt kirjutaja peas, välised parandused on nähtavad produktis - kirjutatud tekstis. Seda jaotust on selgelt näha ka eelnevalt kirjeldatud kirjutamisprotsessi mudelites (Hayes \& Flower 1980; Flower \& Hayes 1981). Mõlemad paranduste tüübid sisaldavad nii vormi- kui ka kontseptuaalset parandamist. Sisemised parandused jagunevad eelkeelelisteks, mis sisaldavad kontseptuaalset laadi parandusi 
nagu plaani, idee/mõtte parandus, ja eeltekstilisteks, mis sisaldavad nii kontseptuaalseid kui ka vormiparandusi. Välised parandused jagunevad kontekstieelseteks ja kontekstisidusateks vastavalt sellele, kas nad esinevad mõtte väljendamise hetkel seni kirjutatud teksti lópus (ingl at the point of inscription) või varasemas tekstis ehk kontekstis.

Paranduste taksonoomiaid hakati välja arendama 1980. aastate alguses. Praeguseks on loodud mitmeid klassifikatsioone, mis keskenduvad kas valmis teksti ehk produkti parandustele või kirjutamisprotsessi käigus tehtud muudatustele (Lindgren \& Sullivan 2006a: 39).

Produktile keskenduvatest taksonoomiatest on levinuim Lester Faigley ja Stephen Witte (1981) oma, mis jagab parandused kahte kategooriasse vastavalt sellele, kas parandus on uue info teksti toonud või mitte (vt joonis 2). Pindmised muudatused, mis ei lisa teksti uut sisu ega eemalda olemasolevat, jagunevad formaalseteks (enamasti grammatilisteks) ja tähendust säilitavateks parandusteks, mis sõnastavad teksti ümber. Tekstipõhised muudatused eristavad suuremaid ehk makrostruktuuri parandusi, mis mõjutavad teksti kokkuvõtet, ja väiksemaid ehk mikrostruktuuri parandusi, mis ei muuda teksti kokkuvõtet. Nii tähendust säilitavad kui ka mikro- ja makrostruktuuri parandused on kirjeldatud tegevuse kaudu: lisandumised (ingl additions), kustutamised (ingl deletions), asendused (ingl substitutions), ümberkorraldused asendustega (ingl permutations), jaotused (ingl distributions) ja (lausete) ühendamised (ingl consolidation). (Faigley \& Witte 1981: 402-405)

Stevenson jt (2006) uurivad nii produkti kui ka kirjutamisprotsessi online-muudatusi vastavalt multidimensionaalsele paranduste taksonoomiale. Klassifikatsioon eristab paranduste põhikategooriaid neljast dimensioonist lähtudes (vt tabel 1): kas parandus on kontseptuaalsel, keelelisel (õigekiri, grammatika, sõnavara, interpunktsioon, sõnastus, aga ka paranduse põhjus: kas selle on põhjustanud viga või mitte) või trükivea tasandil (paranduse liik), kui suurt teksti hulka hõlmab parandus (valdkond), millisel teksti produtseerimise hetkel parandus aset leiab (asukoht) ning mil viisil kirjutaja teksti muudab (tegevus). (Stevenson jt 2006: 205-206, 230-233) 


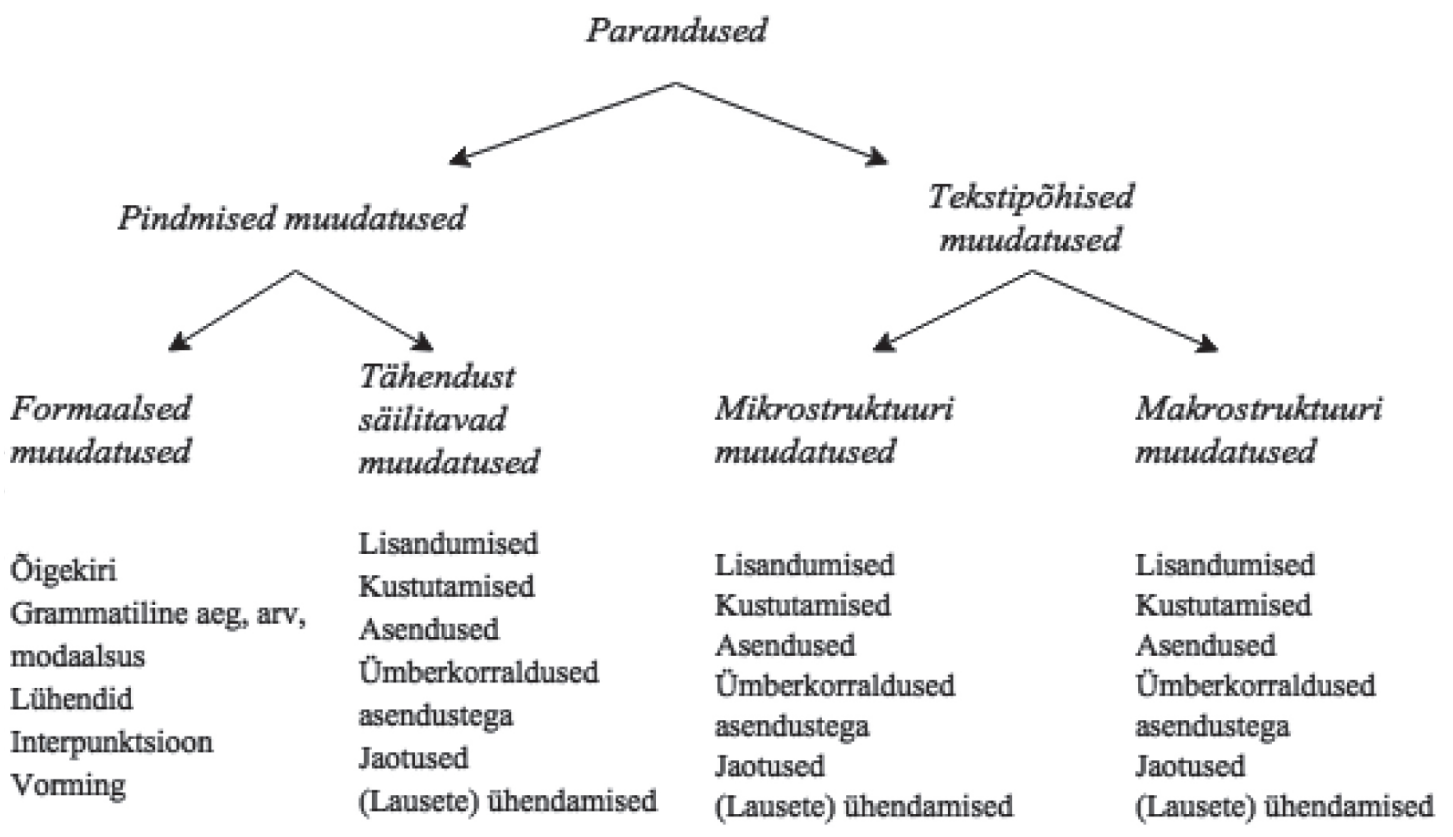

Joonis 2. Faigley ja Witte (1981: 403) paranduste taksonoomia

TABEL 1. Stevensoni jt (2006: 211) multidimensionaalne paranduste taksonoomia

\begin{tabular}{|l|l|}
\hline \multicolumn{1}{|c|}{ Mõõde/dimensioon } & \multicolumn{1}{c|}{ Põhikategooriad } \\
\hline 1. Paranduse liik & Sisu, keel, trükiviga \\
2. Valdkond & Lause või pikem tekst, lause sees, sõna sees \\
3. Asukoht & Eeltekst, jooksva teksti viimase sõna lõpus, \\
& varasem tekst \\
4. Tegevus & Lisandus, kustutus, asendus, muu \\
\hline
\end{tabular}

Ka Lindgreni ja Sullivani (2006b) klassifikatsioon (vt tabel 2) keskendub nii produktile kui ka protsessile, kuid lähtub kõigepealt paranduse asukohast ja siis selle mõjust online-tekstile. Vastavalt paranduste jaotusele tüübi ja asukoha järgi (vt joonis 1) paigutavad autorid kontekstieelsed parandused Van Geldereni ja Oostdami (2004, Lindgren \& Sullivan 2006b järgi) kirjutamismudeli teoreetilisse raamistikku, aga kontekstisidusaid parandusi liigitavad oma LS-taksonoomias. 
TABEL 2. Kontekstisidusa paranduse LS-taksonoomia (Lindgren \& Sullivan 2006b: 172)

\begin{tabular}{|ll|ll|}
\hline \multicolumn{2}{|c|}{$\begin{array}{c}\text { Vormiparandused } \\
\text { Kokkuleppeline/valikuline } \\
\text { OOige/ekslik/neutraalne }\end{array}$} & Kontseptuaalsed parandused \\
\hline Trükivead & Interpunktsioon ja & Tekstipõhised & Tasakaal \\
Õigekiri & vorming & Mikrostruktuur & Teema \\
Parandus & Kirjavahemärgid & Lisandus & Adressaat \\
Asendus & Suurtäht & Kustutus & Register \\
Kustutus & Lõik & Asendus & Muu \\
Homofoonid & Muu vorming & Ümberkorraldus & \\
Grammatika & Tähendust & asendusega & \\
Verb & säilitavad & Jaotus & \\
Ühildumine & Lisandus & Ühendamine & \\
Eessõna & Kustutus & Makrostruktuur & \\
Sidesõna & Asendus & Lisandus & \\
Artikkel & Ümberkorraldus & Kustutus & \\
Pronoomen & asendusega & Asendus & \\
Genitiiv & Jaotus & Ümberkorraldus & \\
Adjektiiv & Ühendamine & asendusega & \\
Adverb & K2-st K1-e & Jaotus & \\
Muu & K1-st K2-e & Ühendamine & \\
\hline
\end{tabular}

Van Geldereni ja Oostdami (2004, Lindgren \& Sullivan 2006b järgi) paranduste mudel selgitab töömälu mahtu, paranduse asukohta (sisemine, väline, kontekstisidus, kontekstieelne) ja paranduse sisu (vorm või tähendus). Nende pakutud kirjutamismudel sisaldab kolme töömälus töödeldud komponenti: kontseptuaalse sisu genereerimise ja paranduse eest vastutav planeerimise komponent (ingl planner), keelevormide ja nende paranduse eest vastutav tõlkimise komponent (ingl translator) ning vormi ja tähenduse vastavuse eest vastutav kontrollimise komponent (ingl reviewer). Siit järeldub, et kontseptuaalsed parandused on kognitiivselt keerulisemad kui vormiparandused, sest nõuavad nii planeerimise kui ka tõlkimise komponenti, vormiparandusi aga opereerib vaid tõlkimise komponent. Lisaks vastutab kontrollimise komponent sisemise ja produtseeritud teksti parandamise kõrval ka kontekstieelse 
sõna või lause eest, mis on vaid osaliselt kirjutatud, olles osaliselt sisemine, osaliselt väline. Sel juhul võib parandamine katkestada transkribeerimise protsessi, sest kahe protsessi samaaegsel esinemisel tekib kognitiivse ülekoormuse oht. Lisaks on kontekstieelsetel parandustel mitmeid põhjusi, nt tehakse parandus kas eelnevalt kirjutatu läbilugemise tulemusel või sobitades loodava teksti sisu teksti üldplaani, või otsides sobivat viisi selleks, et tähendus vormi panna. Ilma kirjutaja seletusteta, millest parandus on esile kutsutud, ei ole kontekstieelseid parandusi lihtne liigitada, kuna alati ei ole parandamise põhjus läbipaistev. Sel põhjusel kirjeldabki LS-taksonoomia väliseid kontekstisidusaid parandusi. (Lindgren \& Sullivan 2006b: 161-162)

Kontekstisidusad parandused on jaotatud vormi- ning kontseptuaalseteks parandusteks. Vormiparandused jagunevad omakorda trükivea, õigekirja, grammatika, interpunktsiooni ja vormingu ning tähendust säilitavate paranduste kategooriateks. Õigekirja, grammatika, interpunktsiooni ning vormingu parandused on täiendavalt liigitatud kokkuleppelisteks ja valikulisteks. Kõigi kokkuleppeliste paranduste puhul kontrollitakse paranduse õigsust. Valikulised parandused on stilistilise või argumenteeriva iseloomuga. Kontseptuaalsed parandused jagunevad tekstipõhiseks ja tasakaalukategooriaks. Tasakaalu parandused kohendavad teksti sel viisil, et see muutuks valmis teksti adressaadile sobivamaks.

Kontekstisidusate paranduste liigitamise lähtekohana kasutavad Lindgren ja Sullivan (2006b) Faigley ja Witte (1981) taksonoomiat, kuid laiendavad seda ja nimetavad mõningad kategooriad ümber, et ühtlustada kontekstieelsete ja kontekstisidusate muudatuste termineid ning LS-taksonoomia ja paranduste jaotus (vt joonis 1). Näiteks säilib Faigley ja Witte (1981) pindmiste ja tekstipõhiste muudatuste jaotus küll vormi- ja kontseptuaalsete paranduste kujul (Lindgren \& Sullivan 2006a, 2006b), Stevensoni jt (2006) taksonoomias aga vastavad nendele keeleliste ja sisuliste paranduste kategooriad. Lindgreni ja Sullivani (2006b) vormiparandused on Faigley ja Witte (1981) pindmistest muudatustest detailsem kategooria, mis kaasab ka muudatusi, mida tehakse emakeelest 
erinevas keeles kirjutamise käigus. Uue kategooriana on kontseptuaalsete paranduste alla lisatud tasakaalu kategooria, mis seletab parandusi, mis mõjutavad teksti pigem stilistilisel tasandil kui vormi ja tekstipõhisel tasandil. Faigley ja Witte (1981), Stevensoni jt (2006) ning ka Lindgreni ja Sullivani (2006b) taksonoomias on ühisjooni paranduse tegevuse osas (nt lisandus, kustutus, asendus jt). Erinevalt Stevensoni jt (2006) multidimensionaalsest paranduste taksonoomiast lähtub aga LS-taksonoomia kõigepealt paranduse asukohast (kontekstisidusad parandused) ja seejärel vaatab tehtud paranduse mõju tekstile. (Lindgren \& Sullivan 2006b: 171-183)

\section{Varasemad uurimused}

Taksonoomiatest lähtudes on uuritud kirjutamisprotsessi parandusi võrdlevalt emakeeles ja võõrkeeles/teises keeles. Nii analüüsisid Stevenson jt (2006) 22 hollandi emakeelega gümnaasiumiõpilase kirjutamisprotsessi parandamist emakeeles ja inglise keeles vastavalt multidimensionaalsele paranduste taksonoomiale. Nende tulemused näitasid, et nii emakeeles kui ka võõrkeeles parandati kõige sagedamini trükivigu, millele järgnesid keelelised ja sisulised parandused. Kuigi keeleparandusi tehti oluliselt rohkem inglise keeles kui emakeeles, esines sisulisi parandusi emakeeles ja võõrkeeles ühtmoodi, mis näitab, et kognitiivsed ressursid ei olnud omavahel võistluses keele ja sisuliste protsesside vahel. Keeleparandustest esinesid inglise keeles sagedamini kui emakeeles õigekirja, grammatika ja sõnavara parandused, kuid interpunktsiooni ja sõnastust parandati mõlemas keeles väga sarnaselt ning need osutusid keelest sõltumata kõige sagedasemateks keeleparanduste tüüpideks. Veast tingitud parandusi esines tunduvalt rohkem inglise keeles, muude paranduste arv oli mõlemas keeles identne. Kõige sagedasemad parandused mõlemas keeles esinesid sõna tasandil, nendele järgnesid parandused lause tasandil ja siis parandused, mis hõlmasid tervet lauset või pikemat teksti. Asukoha osas on mõlemas keeles kõige sagedasemad kontekstieelsed parandused, kuid inglise keeles esines 
neid oluliselt rohkem kui emakeeles. Tegevuse osas on kõige sagedasem paranduse kategooria asendus. Asendusi ja kustutamisi esines oluliselt rohkem inglise keeles kui emakeeles. Kokkuvõtlikult esines kõigi nelja dimensiooni puhul ühe või enama kategooria kõrgem sagedus võõrkeeles, kuid dimensiooni ülejäänud kategooriates jäi paranduste sagedus mõlemas keeles peaaegu identseks. Teisisõnu pühendasid kirjutajad võõrkeeles rohkem tähelepanu teatud paranduste tüüpidele - kontekstieelsetele keeleparandustele, mis hõlmasid leksikaalse üksuse või grammatilise struktuuri asendust -, kuid need parandused olid sagedasemad ka osalejate emakeeles. Kuigi tulemused näitasid, et võõrkeeles on teatud paranduste tüübid sagedasemad kui emakeeles, mis võib viidata osalejate kognitiivsete ressursside ümberjaotusele võõrkeeles kirjutamisel, ei olnud ühtki juhtumit, kui paranduste absoluutne esinemissagedus mõnes kategoorias oleks olnud inglise keeles oluliselt väiksem kui emakeeles. Seega ei ole ülejäänud paranduste tüübid võõrkeeles takistatud. (Stevenson jt 2006: 215-223; Schoonen jt 2009: 87-88)

Lindgren ja Sullivan (2006b) uurisid üheksa rootsi emakeelega kooliõpilase kirjutamisprotsessi kontekstieelseid ja kontekstisidusaid parandusi emakeeles ja inglise keeles. Erinevalt Stevensoni jt (2006) uurimusest näitavad nende tulemused, et tervikuna tehti mõlemas keeles kontekstisidusaid parandusi rohkem kui kontekstieelseid. Kontekstieelsed parandused sõltusid keelest: võõrkeeles parandati vormi ja sisu tunduvalt rohkem kui emakeeles - tulemus, mis ühtib varasemate uurimustega (Silva 1993; Thorson 2000). (Lindgren \& Sullivan 2006b: 168-170)

Emakeeles ja võõrkeeles/teises keeles kirjutamise protsessi paranduste võrdleva uurimise kõrval on uuritud ka ainult teises keeles kirjutamisel tehtud parandusi. Baraa Khuder ja Nigel Harwood (2015) uurisid olukorra mõju inglise keeles teise keelena kirjutamisele, võrreldes 10 erineva emakeelega üliõpilase kirjutamist inglise keeles testi- ja tavaolukorras. Nende tulemused näitavad, et osalejatel kulus testiolukorras rohkem aega lausetasandi kontekstieelsetele pindmistele parandustele, öeldut ümber sõnastades, tavaolukorras keskendusid nad aga rohkem 
kontekstisidusatele sisulistele parandustele kirjutatud mõtteid muutes, lisades või kustutades. Uurimusest järeldub, et teises keeles kirjutamise protsessi parandamist mõjutab olukord: tavaolukorras osalejad kirjutavad ja siis parandavad sisu, aga testiolukorras ajapiirangu tõttu nad esialgu plaanivad hoolikalt ja siis alustavad kirjutamist. (Khuder \& Harwood 2015: 254-264)

Seega keskenduvad varasemad uurimused peamiselt emakeeles ja teises keeles kirjutamise protsessi võrdlusele ning näitavad, et teises keeles kirjutamisel esineb parandusi rohkem kui emakeeles (Silva 1993; Thorson 2000; Lindgren \& Sullivan 2006b) ja teises keeles kirjutajad piirduvad enamasti vormiparandustega (Chenoweth \& Hayes 2001). Samas on vähe uuritud, kuidas on teises keeles kirjutamise protsess ja keeleoskustasemed omavahel seotud, kuidas kirjutamisprotsess muutub, kui keeleoskus kasvab. Chenoweth ja Hayes (2001) leidsid oma uurimuses, et väiksema keeleoskusega osalejate kirjutamisprotsessi katkestas sagedasem paranduste arv ning et kõrgem keeleoskustase oli seotud suurema sujuvusega kirjutamisel. Niisiis põhjustab sujuvuse puudus teises keeles leksika otsimist ning vormivigade parandamist, mis katkestab pidevalt tekstiloomet. Emakeeles on kirjutamisprotsess automaatsem ning seetõttu ka sujuvam ning see vabastab töömälu, keskendumaks sisulistele parandustele erinevalt teises keeles kirjutamisest, kus keskendutakse vormile. (Chenoweth \& Hayes 2001: 89-96; Lindgren \& Sullivan 2006a: 33) Tuleb mainida, et Chenoweth'i ja Hayes'i (2001) uurimuses on keeleoskus määratletud sihtkeelt õpitud semestrite arvuga. Kirjutamisprotsessi sujuvuse ja "Euroopa keeleõppe raamdokumendi" keeleoskustasemete seost on uuritud soome emakeelega rootsi keele õppijatel (Palviainen jt 2012).

Eesti keele õppijate vigu kirjalikes tekstides on varem liigitanud Anna Verschik (2004: 135-141), kes uuris Narva Kolledži eesti keele kui teise keele eriala üliõpilaste kirjutatud tekstides esinenud morfosüntaksi, semantika ning sõnamoodustuse vigu, jättes vormimoodustusvead analüüsist välja, ning leidis, et konkreetses sotsiolingvistilises olukorras on sagedasimad semantikavead (19\%). Kõrgtasemel eesti keelt teise keelena 
kõnelejate ning emakeelekõnelejate vigu kirjalikus keelekasutuses on võrdlevalt uurinud ja detailselt liigitanud Raili Pool ja Elle Vaimann (2005). Nende materjal on kogutud Tartu Ülikooli formaalse eesti keele õppe läbinud ja eesti keelt Eestis kehtinud standardtestide järgi kõrgtasemel valdavate üliõpilaste eesti keele lõpueksami esseedest. Tulemused näitavad, et teise keele kõnelejate kõige sagedasemate vigade hulka kuuluvad sõnajärje $(17,6 \%)$, sõnavaliku (13,9\%), täis- ja osasihitise $(9,9 \%)$, sõnastuse $(6,6 \%)$ vead, emakeelekõnelejatel on sagedasemateks vealiikideks kokku- ja lahkukirjutamine $(15,9 \%)$, sõnajärg (13,9\%), sõnastus (9,9\%), sõnavalik (6,9\%). (Pool \& Vaimann 2005: 118-133) Samuti on Pool ja Vaimann (2006) võrrelnud venekeelsete üliõpilaste kesk- ja kõrgtaseme vigu kirjalikes eksamitöödes ning leidnud, et nii kesk- kui ka kõrgtasemel on esinemissageduselt esimesel kohal sõnajärje ja teisel kohal sõnavaliku vead, mis näitavad tugevat stabiliseerumistendentsi. Märgatav edasiminek (vigade vähenemine) on keeleoskuse suurenedes vormi- ja sõnamoodustuses ja tagasilangus (vigade arvu suurenemine) sõnastuse vealiigis. (Pool \& Vaimann 2006: 208-211) Mõlemas uurimuses on tegemist produkti ehk valmis teksti jäänud vigadega, mida on hinnatud emakeelekõneleja keeletaju järgi. Kirjutamisprotsessi uurimine võimaldab lisaks teada saada, kas ja mida on kirjutajad ise teksti produtseerimise jooksul parandanud ning mis valdkonnad tekitavad neile raskusi tehtud muudatuste vaatenurgast.

Eesti keeles kirjutamise protsessi on keeleoskustasemeti uuritud venekeelsetel eesti keele õppijatel mikrokonteksti mõiste abil, lähtudes arvutiprogrammiga kogutud üleminekute andmetest ühelt klahvilt teisele teatud ümbruses teksti arvutis kirjutamise jooksul (Pastuhhova 2015). Mikrokontekstide analüüsi tulemused näitavad, et vene emakeelega üliõpilaste kirjutamist eesti keeles kui teises keeles iseloomustab igal keeleoskustasemel (A2-st C1-ni) suur hulk parandusi. Sõna tasandil (sõna sees ja sõnade vahel) tehakse kõige rohkem parandusi B2-tasemel. Järjestikused kustutamised ja/või hiireliigutused suurenevad A2-tasemest kuni C1-tasemeni, kusjuures need ületavad C1-tasemel rohkem kui kaks korda A2-taseme hulga, mis näitab, et isegi keeleoskuse kasvades 
iseloomustab kirjutamisprotsessi teksti pidev muutmine ja täiendamine. (Pastuhhova 2015: 212-213) Mikrokontekstide analüüsi tulemustest kasvab välja käesolev uurimus, mille eesmärgiks on sama uurimismaterjali üksikasjalikum kirjutamisprotsessi parandamise kirjeldus ning paranduste ja keeleoskustaseme seose käsitlus.

\section{Uurimisküsimused, materjal ja osalejad}

Eelduse kohaselt katkestavad kirjutamist madalama (A2, B1) keeleoskuse puhul sagedasemad parandused, keeleoskuse tõusuga B2- ja C1-tasemel nende arv väheneb. Samas näitab mikrokontekstide analüüs rohket parandamist B2-tasemel. Siinses artiklis käsitletavas uurimuses otsitakse vastust järgmistele küsimustele:

1) Millised kirjutamisprotsessi parandused iseloomustavad keeleoskustasemeid ning mida need parandused ütlevad keeleomandamise kohta? Kuidas parandused jaotuvad tegevuse, liigi, asukoha ning valdkonna järgi ning kuidas muutub nende osakaal keeleoskustasemeti?

2) Millele keskendab keeleõppija oma tähelepanu igal keeleoskustasemel kirjutamisprotsessi jooksul tehtud paranduste vaatenurgast? Mis valmistab enim raskusi kirjutamisel ning kuidas muutub probleemsete valdkondade jaotus keeleoskuse tõusuga?

Hüpotees on, et madalamat keeleoskustaset (A2, B1) iseloomustab suurem vormiparanduste arv, mis väheneb keeleoskuse tõusuga, aga kõrgematele tasemetele (B2, C1) on omased sisulised parandused, millele pööratakse rohkem tähelepanu keeleoskuse paranedes. Teine hüpotees on, et madalama keeleoskustaseme (A2, B1) puhul parandatakse kontekstieelselt vormi, kõrgema keeleoskustaseme (B2, C1) puhul pigem sisu, jättes vormi kontekstisidusaks paranduseks.

Uurimismaterjal on kogutud klaviatuuri klahvivajutuste salvestuse meetodil põhineva ScriptLog-programmiga Tallinna Ülikooli vene emakeelega üliõpilastelt, kes osalesid eesti keele kursusel erinevates rühmades vastavalt oma keeleoskustasemele ning kes olid nõus eesti keele 
kirjutamisprotsessi käsitlevas uurimuses osalema. Uurimuses osales 34 venekeelset üliõpilast, kellel paluti kirjutada uurija arvutis ning tema juuresolekul loovkirjutis haridusteemal. Loovkirjutise teema oli antud osalejate eeldatava taseme järgi. 17 tugevamal tudengil paluti kirjutada arutlev tekst teemal "Kas kõigile on vaja kõrgharidust" ja 17 nõrgemal tudengil jutustav tekst teemal "Mida on mulle andnud ülikool". Teksti kirjutamiseks oli aega antud üks tund, sõnaraamatuid ega muid materjale ei lubatud kasutada. Loovkirjutise valmimisel paluti osalejatel retrospektiivselt kommenteerida kirjutamisprotsessi ning esinenud raskusi, intervjuud lindistati. Loovkirjutiste valmimise järgselt hindas neid kaks eksperti, kelle hinnangul vastas osalejate eesti keele oskus antud ülesande järgi "Euroopa keeleõppe raamdokumendi” neljale keeleoskustasemele järgnevalt: 4 teksti vastasid A2-tasemele (kõik jutustavad tekstid), 13 teksti B1-tasemele (12 jutustavat teksti, 1 arutlev), 13 teksti B2-tasemele (12 arutlevat teksti, 1 jutustav) ja 4 teksti C1-tasemele (kõik arutlevad tekstid). Kõik tekstid moodustavad artiklis käsitletava uurimuse materjali, intervjuude analüüsi ei võimalda käesoleva artikli piiratud maht.

\section{Uurimuse metodoloogia}

Uurimus käsitleb venekeelsete üliõpilaste parandusi eesti keeles kirjutamisel. Tegemist on kirjutamisprotsessi parandustega ning nad kõik ei pruugi lõplikus tekstis kajastuda, vaid võivad järgnevate paranduste käigus muutuda. Seega näitab kirjutamisprotsessi paranduste analüüs kognitiivse tegevuse suunda kogu teksti kirjutamise ajal ehk millele on kirjutaja tähelepanu suunatud protsessi jooksul, kuidas ta liigub tekstis produtseerimise vältel ning mis järjestuses oma mõtteid väljendab. Paranduste uurimiseks on iga osaleja puhul analüüsitud ScriptLogprogrammiga salvestatud kirjutamisprotsessi lineaarseid tekste, kustutamiste andmefaile ja logifaile. Paremaks arusaamiseks on vajadusel kirjutamissessioonid reaalajas taas esitatud, mis loob tervikpildi teksti kirjutamise kohta. 
Uurimisküsimustele vastuse leidmiseks ning kirjutamisprotsessi parandamise kirjeldamiseks on kasutatud Stevensoni jt (2006) multidimensionaalset paranduste taksonoomiat ning lisaks kontekstisidusate paranduste LS-taksonoomiat (Lindgren \& Sullivan 2006b). Kuigi Lindgren ja Sullivan (2006b) rõhutavad kontekstisidusate paranduste analüüsi suuremat objektiivsust, käsitleb käesolev uurimus nii kontekstisidusaid kui ka kontekstieelseid parandusi. Kontekstieelseid parandusi on analüüsitud parandatud teksti seisukohast. Juhul kui parandus ei ole arusaadav, moodustavad need parandused määratlemata kategooria.

Parandusi on analüüsitud neljast dimensioonist lähtudes: kõigepealt paranduse tegevust, siis liiki, asukohta ning valdkonda. Tegevuse osas eristab uurimus kustutamistele järgnevaid asendusi ja lisandumisi. Asenduste uurimiseks on manuaalselt analüüsitud ja liigitatud kõik kustutamised trükivea, vormi või kontseptuaalse paranduse seisukohast. Liigitamisel on püütud lähtuda kontekstisidusate paranduste LS-taksonoomiast, mida on varem kohandatud ka kontekstieelsete paranduste liigitamisele (Nordqvist Palviainen 2007). Trükivead on toodud välja eraldi kategooriana. Nende liigitamisel on lähtutud Stevensoni jt (2006: 231) kriteeriumidest, lisaks arvati trükivigade hulka õige klahvi otsimine, tähelepanematus või tühikud. Vormiparandustest on eristatud ortograafia, morfoloogia, verbi, noomeni, sõnajärje ning interpunktsiooni ja vormingu parandusi. Verbi parandused hõlmavad pöördelõppe, ühildumist, kõneviisi, tegumoodi ja infinitiivi valikut. Noomeni paranduste alla on koondatud käändelõpu, arvu ja ühildumise parandused. Interpunktsiooniparandused hõlmavad kirjavahemärke, kaasa arvatud need juhud, kui otsustatakse lauset jätkata või vastupidi, lõpetada. Kontseptuaalsed parandused on sisulist laadi parandused, mida on jagatud sõnavaliku ja sõnastuse kategooriateks. Kui sõnavalik piirdub ühe sõnaga, puudutavad sõnastuse parandused väljendites tehtud parandusi, aga ka tihti sõnades lause alguses tehtud parandusi, kui on raskusi kogu lause produtseerimisega. Sellist olukorda iseloomustab sageli mitu järjestikust parandust. Täienduse alla on koondatud need juhud, kui hakatakse kirjutama, kuid kustutatakse selleks, et teksti täiendada ja siis sama jätkata. 
Juhud, kui alustatakse kirjutamist, kustutatakse ja siis jätkatakse nii nagu enne kustutamist, on koondatud muutmata jätkamise alla. Tuleb mainida, et täienduse ja muutmata jätkamise kategooria parandused on tehtud vaid osaliselt kirjutatud sõna puhul ning on osaliselt välised kontekstieelsed ja osaliselt sisemised eeltekstilised parandused. Korduse parandused on eelnevate paranduste tagajärg ning moodustavad väikse kategooria, kus kustutusele ei järgne otsene asendus. Neid juhtumeid ei ole palju, siiski on nad eraldi kontseptuaalsete paranduste all ära toodud. Varasemasse teksti lisatud tekst on jagatud mikro- ja makrostruktuuri lisandumisteks vastavalt sellele, kas nad mõjutavad teksti lokaalselt või globaalselt (Lindgren \& Sullivan 2006b: 180). Lisatud üksiksõnad on mikrostruktuuri tasandil, osalaused, laused või lõigud on koondatud makrostruktuuri lisandumiste alla, kuna nende mõju tekstile on globaalsem. Ka kontekstieelsed ja kontekstisidusad sõnavaliku ja sõnastuse parandused võiks liigitada mikro- ja makrostruktuuri parandusteks, kuid käesolev uurimus nimetab neid sõnavaliku ja sõnastuse parandusteks. Lisaks ei eristata käesolevas uurimuses erinevalt LS-taksonoomiast sõnavaliku ja sõnastuse ümbersõnastusi muudest sõnavaliku ja sõnastuse parandustest, need on koondatud kontseptuaalsete paranduste kategooriasse kui sõnalises väljenduslaadis aset leidvad sisulised muudatused. Seega on käesoleva uurimuse materjalist tulenevalt kasutatud paranduste liigitamisel järgmisi kategooriaid: trükivead; vormiparandused: ortograafia, morfoloogia, verb, noomen, sõnajärg, interpunktsioon ja vorming; kontseptuaalsed parandused: asenduste puhul sõnavalik, sõnastus, täiendus, muutmata jätkamine ning kustutus, lisandumiste puhul mikro- ja makrostruktuuri lisandused. Kuigi käesolevas uurimuses on lähtutud LS-taksonoomiast, esineb siin paranduste liigitamisel uurimismaterjalist tulenevalt erinevusi: nt mikro- ja makrostruktuuri parandustest käsitletakse lisandusi, kontseptuaalseteks parandusteks loetakse sõnavaliku ja sõnastuse parandusi, vormiparandustena ei loeta sõnavaliku ja sõnastuse ümbersõnastusi, tasakaalu kategooriat ei esine. Kuna käesoleva artikli eesmärk on kirjeldada kirjutamisprotsessi parandusi keeleoskustasemeti, jääb LS-taksonoomia detailsem analüüs ja selle 
adapteerimine eesti õppijakeele kirjutamise uurimiseks artikli piiratud mahu tõttu edasiste käsitluste teemaks.

Asukoha dimensiooni osas järgitakse jaotust kontekstieelseteks ja kontekstisidusateks parandusteks. Kuna lisandumised on varasemasse teksti lisatud, on nad loetud kontekstisidusateks parandusteks. Kustutamistejärgsed asendused on jaotatud vastavalt programmiga kogutud andmetele, mis näitavad, mitu tähemärki kursorist eespool või tagapool on parandus tehtud. Kui parandus on kursori asukoha kohas, on tegemist kontekstieelse parandusega, enne kontekstisidusat parandust on kursor nihutatud tekstis kas ette- või tahapoole.

Valdkonnaparandustel on kolm kategooriat: sõna (sees), mis sisaldab ka terve sõna parandusi; lause sees ning lause või pikem tekst, kui asendus või lisandus on puudutanud kas lauset tervikuna või pikemat teksti, kaasa arvatud lõigud. Valdkonnaparanduste puhul on välja arvatud trükivead, interpunktsiooni ning vormingu parandused.

Erinevalt LS-taksonoomiast ei käsitle käesolev uurimus paranduste õigsust, vaid keskendub kirjutamisprotsessi jooksul esinenud parandustele ning käsitleb parandustes väljendunud protsessi ja selle raskusi. Siinses uurimuses ei analüüsita, kas paranduse põhjustas viga ega ka seda, kas viga sai õigeks parandatud. Uurimuses on analüüsitud ka neid juhtumeid, kui hoopis õige vorm sai parandatud vääraks. Seega näitab uurimuse materjal osalejate tähelepanu fookust kirjutamisprotsessi ajal.

\section{Tulemused}

Uurimuse tulemused on esitatud neljas kategoorias vastavalt multidimensionaalsele taksonoomiale, alustades tegevuse dimensioonist, millele järgneb liigi, asukoha ja valdkonna dimensioon. Kuigi uurimisküsimustele vastuse leidmiseks on kirjeldatud taksonoomia kõiki dimensioone, on käesolevas artiklis kõige pikemalt analüüsitud paranduste liigi ja asukoha dimensioone, millest on eraldi välja toodud vormija kontseptuaalsete paranduste suundumused ning kontekstieelsete ja -sidusate paranduste erinevus keeleoskustasemeti. Liigi dimensioon 
sisaldab lisaks analüüsitud materjali üldandmeid, valdkonna dimensiooni esitus on kõige põgusam. Tulemused on esitatud kümnendikutäpsusega keskmiste arvudena teksti kohta keeleoskustasemeti ning paranduste jaotuse osakaalud keeleoskustasemete kaupa ka protsentides. Paranduste dünaamikat on illustreeritud graafikute abil. Tulemusi võrreldakse varasemate uurimustega, mille puhul on oluline eristada kirjutamisprotsessi ja produkti uurimise tulemusi. Käesolevas artiklis käsitletakse kirjutamisprotsessi parandusi (õppija enda tehtud parandused, mille kvalitatiivset olemust selles artiklis ei käsitleta) ja võrreldakse Pooli ja Vaimanni (2006) poolt läbi viidud produktiuurimuse tulemustega (uurija poolt tehtud parandused, mida õppijad ise pole märganud). Kui protsessi uurimine näitab, mis teksti kirjutajate arvates nõuab parandamist, näitab produkti uurimus vigu, mis ikka valmis teksti sisse jäävad. Kirjutamisprotsessi võrdlus produktiga käesoleva uurimismaterjali näitel jääb edaspidiseks uurimiseks.

\subsection{Parandused tegevuse järgi}

Kõigepealt esitatakse uurimuses analüüsitud paranduste üldandmed ja paranduste arvuline jaotus tegevuse järgi asendusteks ja lisandumisteks, lisaks paranduste ja nende jaotuse keskmised arvud teksti kohta igal keeleoskustasemel.

Tabelisse 3 on koondatud paranduste arvandmed tervikuna eraldi trükivigadega ja trükivigadeta. Uurimismaterjal sisaldab 34 teksti kirjutamise käigus tehtud 3349 parandust, millest poole moodustavad trükivigade parandused, ülejäänud 1679 koosnevad vormi- ja kontseptuaalsetest parandustest. 
TABEL 3. Paranduste jaotuse ja hiireliigutuste üldarv

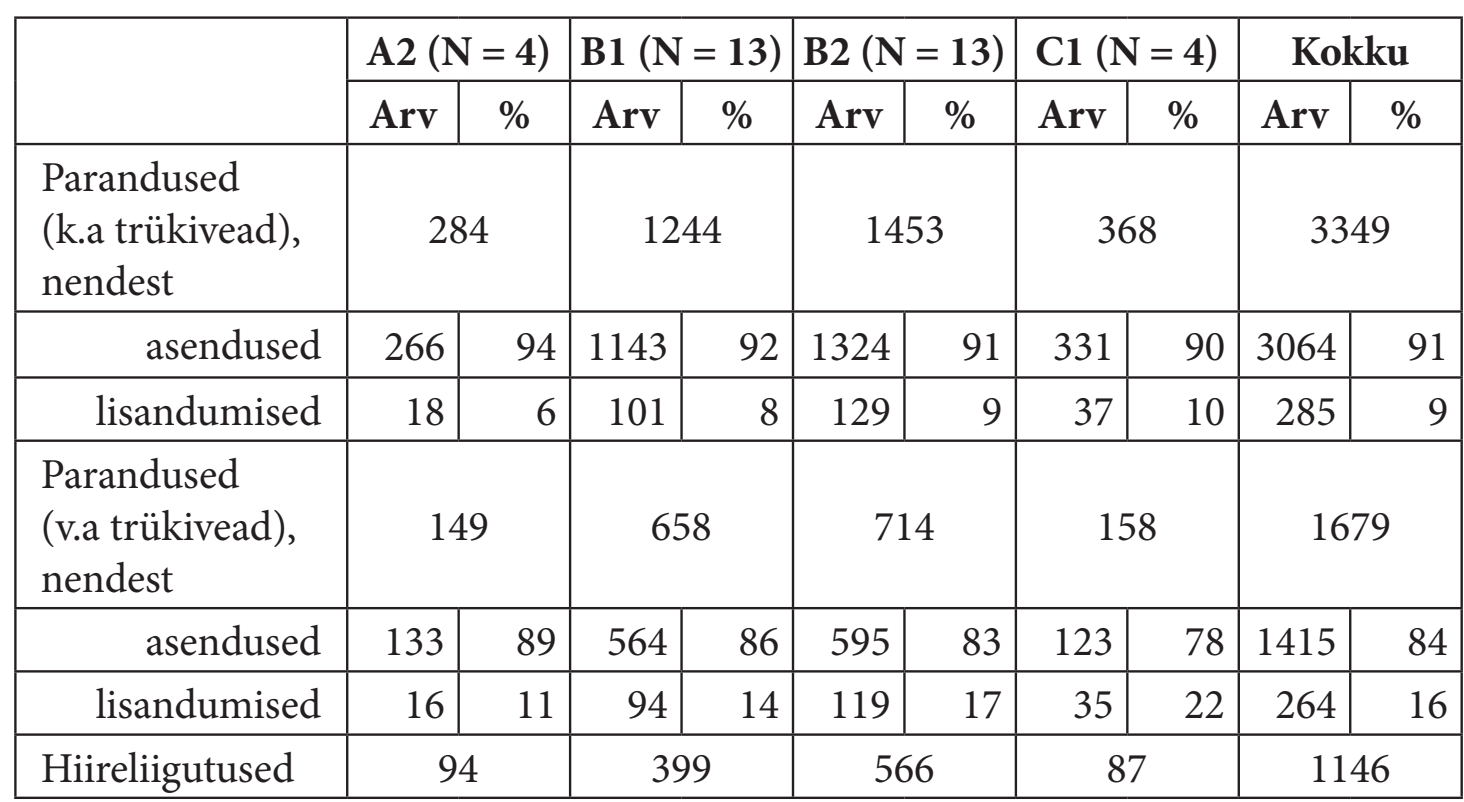

Kui võrrelda paranduste jaotust tegevuse järgi, siis valdava enamiku moodustavad asendused. Teksti muudetakse kustutusjärgselt oluliselt rohkem, kui täiendatakse. Kui võrrelda asenduste ja lisandumiste osakaalu ühe taseme raames, siis keeleoskuse tõusuga asenduste osakaal kogu paranduste arvust taseme kohta langeb ja lisandumiste osakaal suureneb. Teisisõnu, kui paraneb keeleoskus, nihkub kirjutajate fookus teksti kustutamise ja vigade parandamise kõrval varasemalt kirjutatud teksti täiendamisele. Sarnaselt siinsete tulemustega oli ka Stevensoni jt (2006: 218) uurimuses leitud, et asendused on kõige sagedasem kategooria, kuid lisandumised olid nende uurimismaterjalis haruldased. Käesolev uurimus näitab lisandumiste ja keeleoskustaseme seost: mida paremini keelt osatakse, seda rohkem kirjutatud teksti täiendatakse.

Kui tabel 3 näitab parandusi ja nende jaotust tegevuse järgi üldarvudes ning asenduste ja lisandumiste osakaalu protsentides, illustreerib joonis 3, kuidas muutuvad nii paranduste tervikuna kui ka asenduste ja lisandumiste keskmised arvud teksti kohta keeleoskustasemeti. 


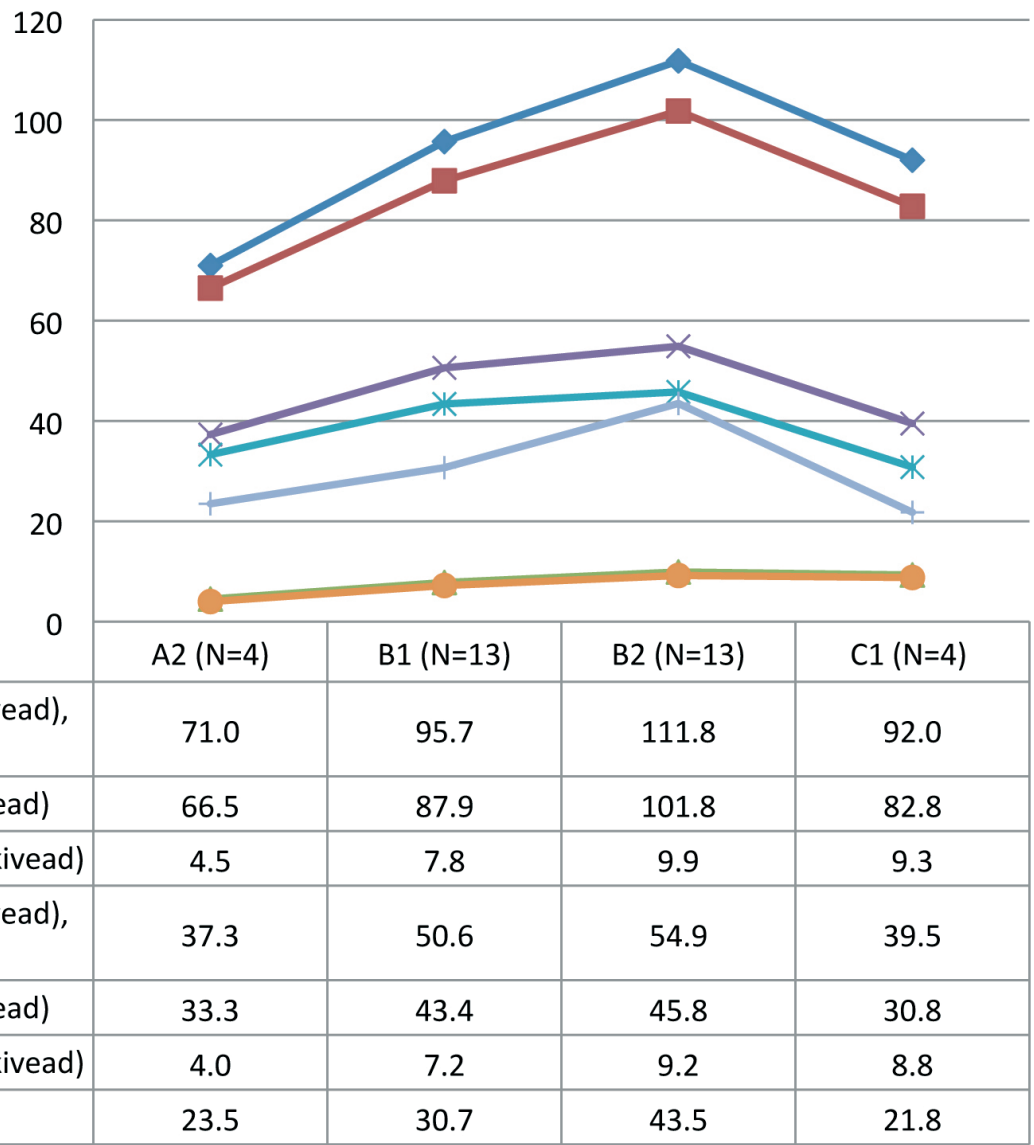

Joonis 3. Paranduste ja hiireliigutuste keskmine arv teksti kohta, paranduste jaotus tegevuse järgi

Joonisest järeldub, et teksti parandatakse minimaalselt A2-tasemel ja maksimaalselt B2-tasemel, kusjuures paranduste keskmised arvud teksti kohta on üpris suured: A2-taseme teksti kirjutamisel parandatakse teksti keskmiselt 71 korda, B1-taseme teksti kirjutamisel 96 korda, B2-taseme tekstis ületab muudatuste arv saja ning C1-taseme tekstis esineb keskmiselt 92 parandust. Paranduste arv tõuseb alates A2-tasemest ning saavutab maksimumi B2-tasemel, mille järel langeb. Sarnaselt paranduste üldtendentsiga suurenevad nii asendused kui ka lisandumised eraldi võetuna A2-tasemest B2-tasemeni, mille järel vähenevad. Siit on näha, et just iseseisvat keelekasutajat iseloomustab rohke teksti parandamine. Edasijõudnu tase (B2) ei tähenda kirjutamisprotsessi käigus kohest korrektset keelekasutust, pigem näitabki suur paranduste arv keele harjutamist, 
lingvistiliste teadmiste rakendamist ja keeleoskuse kasvu. Küll aga muutub vilunud keelekasutaja vaba suhtluse pädevuse tasemel (C1) kirjutamine automaatsemaks ning kirjutajate arvates korrektsemaks.

Lisaks on tabelis 3 ja joonises 3 esitatud hiireliigutuste arvud. Käesoleva artikli autori (Pastuhhova 2015) eelmises uurimuses esitati andmed järjestikuste kustutamiste ja/või hiireliigutuste mikrokontekstide suure hulga kohta tervikuna, mis suurenes A2-tasemest C1-tasemeni. Siin toodud hiireliigutuste arv näitab, et need moodustavad mikrokontekstide osa ning nende arv tõuseb parandustega sarnaselt A2-tasemest B2-tasemeni ning C1-tasemel väheneb. Paranduste kõrval osutab ka hiireliigutuste suur hulk, et kirjutamisprotsessi jooksul on iga taseme tekstis palju liikumisi, eriti edasijõudnu tasemel, mis tähendab omakorda rohket teksti töötlemist keeleoskuse edasimineku tulemusena.

\subsection{Paranduste jaotus liigiti}

Järgnevalt analüüsitakse parandusi jaotuna trükivigadeks, vormi- ja kontseptuaalseteks parandusteks ning arusaamatute muudatuste puhul määratlemata kategooriaks, seejärel esitatakse vormi- ja kontseptuaalsete paranduste suundumused keeleoskustasemeti.

Joonis 4 näitab, mis nõuab kirjutajate hinnangul teksti produtseerimisel parandamist ehk mis köidab nende tähelepanu kirjutamisprotsessi jooksul.

Trükivigade parandused on kõigil tasemetel esimesel kohal, neile järgnevad kontseptuaalsed parandused ja siis vormiparandused. Stevensoni jt (2006: 215) uurimuses olid kõige sagedasemad trükivigade parandused, neile järgnesid keelelised ja ainult väga harva esinenud sisulised muudatused. Käesoleva uurimuse tulemused erinevad Stevensoni jt omast selle poolest, et siin loetakse kontseptuaalseteks parandusteks teksti sõnalises väljenduslaadis aset leidvad sisulised muudatused, sellest tuleneb ka nende suurem arv. Keeleoskusest sõltumata tekitab teksti sisu edasiandmine rohkelt raskusi kõigil tasemetel, kusjuures keeleoskuse tõusuga suureneb kontseptuaalsete paranduste osakaal. 


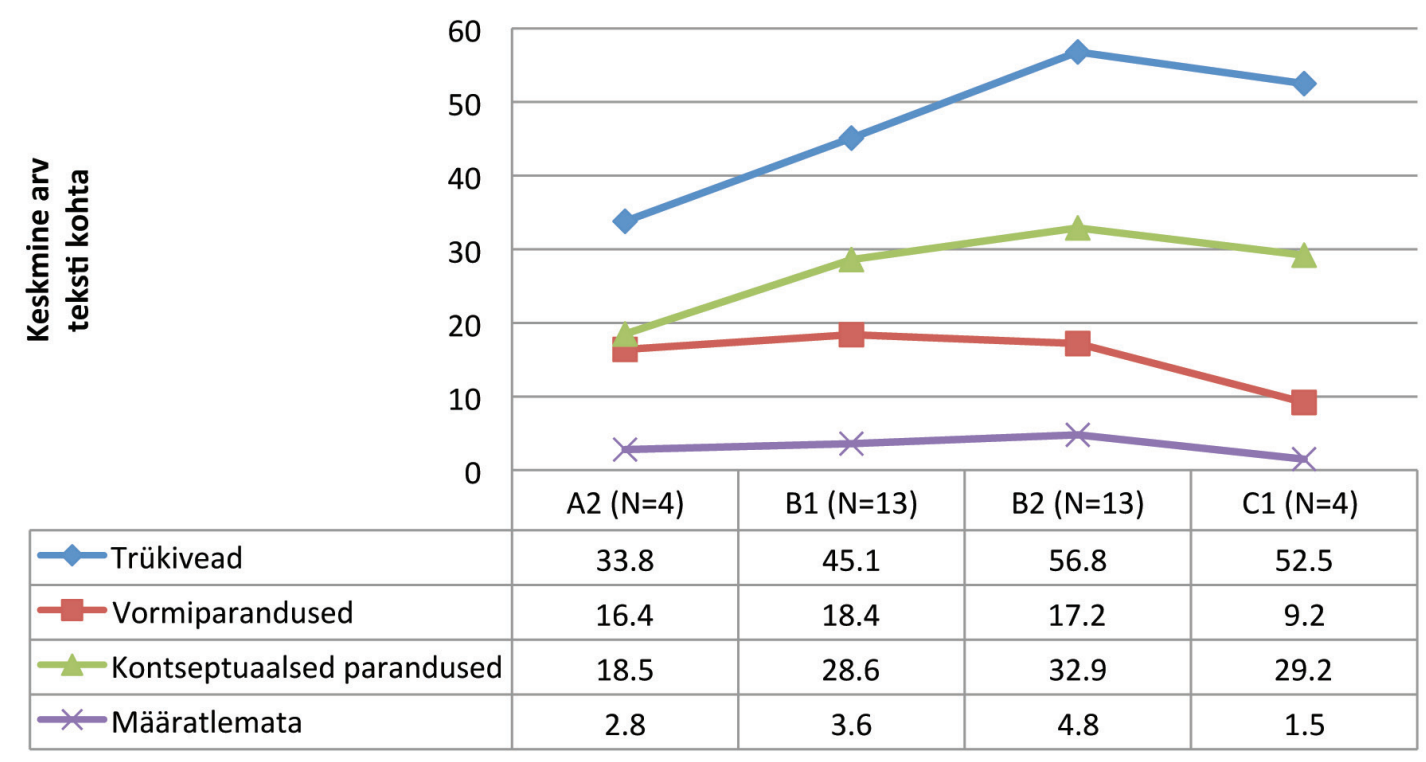

Joonis 4. Paranduste keskmine arv teksti kohta liigiti

Kuigi keeleoskustaseme tõustes kasvab sõnavara, jääb õige sõna valik ja sõnastus probleemiks, mille lahendamisele suunatakse teksti kirjutamisel üha rohkem tähelepanu. Grammatikat aga parandatakse kõigil tasemetel vähem. Keeleoskuse tõusuga kasvavad grammatilised teadmised ning paranduste arv B1-tasemel veidi tõuseb, kuid hiljem langeb, olles C1-tasemel minimaalseim ja umbes kaks korda väiksem kui A2-tasemel. Kui võrrelda vormi- ja kontseptuaalsete paranduste keskmist arvu, siis esmase keeleoskuse tasemel (A2) on mõlemad väga lähedased, mis tähendab, et vähese keeleoskusega kirjutaja tähelepanu on peaaegu võrdselt suunatud nii vormi kui ka sisu parandamisele, keeleoskuse tõusuga aga keskendutakse enam teksti sisu sõnastamisele ja vormiparanduste osakaal väheneb.

Tabel 4 näitab võrdlevalt trükivigade, kontseptuaalsete ja vormiparanduste osakaalu protsentides ühe taseme raames, millest järeldub, et trükivigade arv kasvab käesoleva uurimuse põhjal alates B2-tasemest. Selle tulemuse põhjuste väljaselgitamine vajab täiendavat uurimist. Keeleoskuse tõusuga on vilunud keelekasutaja tasemel (C1) vormiparanduste osakaal rohkem kui kaks korda väiksem kui esmase keeleoskuse tasemel (A2). 
TABEL 4. Paranduste osakaal liigiti

\begin{tabular}{|l|c|c|c|c|}
\hline \multicolumn{1}{|c|}{ Paranduste liik } & $\mathbf{A 2}(\mathbf{N}=\mathbf{4})$ & $\mathbf{B 1}(\mathbf{N}=\mathbf{1 3})$ & $\mathbf{B 2}(\mathbf{N}=\mathbf{1 3})$ & $\mathbf{C 1}(\mathbf{N}=\mathbf{4})$ \\
\hline Trükivead & $47 \%$ & $47 \%$ & $51 \%$ & $57 \%$ \\
\hline Vormiparandused & $23 \%$ & $19 \%$ & $15 \%$ & $10 \%$ \\
\hline $\begin{array}{l}\text { Kontseptuaalsed } \\
\text { parandused }\end{array}$ & $26 \%$ & $30 \%$ & $30 \%$ & $31 \%$ \\
\hline Määratlemata & $4 \%$ & $4 \%$ & $4 \%$ & $2 \%$ \\
\hline
\end{tabular}

Kontseptuaalsed parandused suurenevad alates A2-tasemest, kuid nende osakaal kõigist parandustest taseme kohta jääb sarnaseks, sest trükivigade arv suureneb igal järgneval tasemel. Kirjutamisprotsessi vormiparanduste vähenemise puhul võib tuua paralleele ka Pooli ja Vaimanni (2006: 210-211) uurimuse tulemusega, et kõrgtasemel esineb tekstis ehk produktis kesktasemega võrreldes märgatavalt vähem vormi-, sõnamoodustus- ja ka rektsioonivigu. Vormiparanduste vähenemist keeleoskuse tõustes seletab sihtkeele grammatilise struktuuri ja reeglite omandamine, samuti sihtkeele sagedasem kasutus ning grammatilistel teadmistel põhinev automaatsemaks muutuv keelekasutus. Parandamist nõudev teksti sisu edasiandmine kipub keeleoskuse paranedes stabiliseeruma. Kui siinses artiklis käsitletavas uurimuses vaadeldakse teksti parandamise vajalikkust kirjutajate seisukohast, näitab Pooli ja Vaimanni (2006: 210-211) poolt läbi viidud eesti keele õppijate veaanalüüs, et sõnavara jääbki probleemiks nii kesk- kui ka kõrgtasemel. Sõnavalik jääb nende uurimuses sageduselt vigade üldarvust teisele kohale, sõnastusvigade suurenev arv näitab aga isegi tagasilangust. Käesoleva uurimuse esimeseks hüpoteesiks oli madalamatele keeleoskustasemetele omaste vormiparanduste arvu vähenemine keeleoskuse tõustes ja kõrgemaid tasemeid iseloomustavate sisuliste paranduste kasv, kuid kirjutamisprotsessi paranduste jaotus kinnitab vaid osaliselt esimest hüpoteesi. Kui trükivead välja arvata, köidab kirjutajate tähelepanu kõigil tasemetel esiteks sisu edasiandmine ja alles seejärel grammatika. Vormiparanduste keskmine arv teksti kohta väheneb alates B1-tasemest ning sisuliste paranduste keskmine arv suureneb kuni B2-tasemeni.

Joonis 5 näitab vormiparanduste jaotust. 


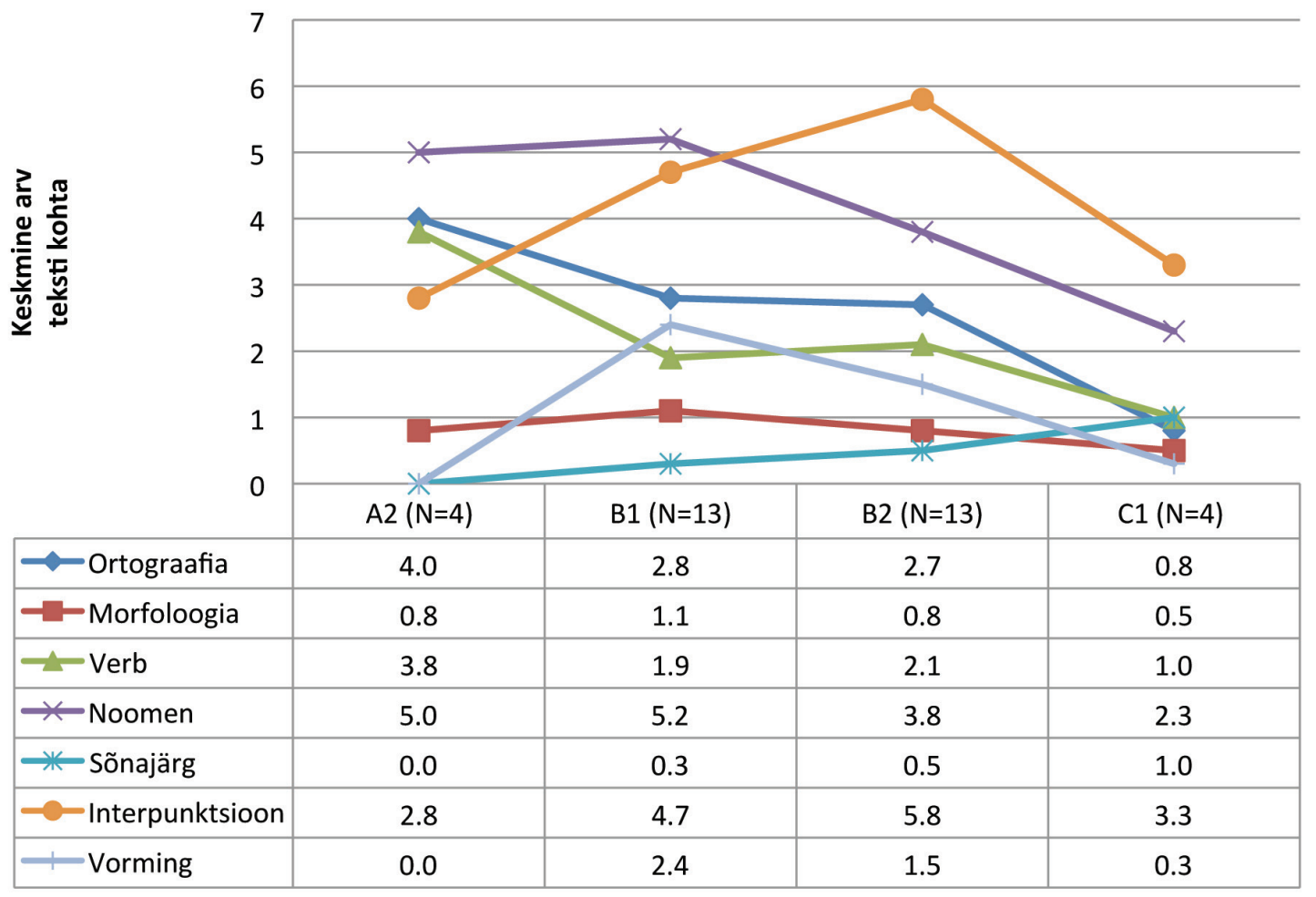

Joonis 5. Vormiparanduste keskmine arv teksti kohta

A2-tasemel on kõige sagedasemad noomeni-, ortograafia- ja verbiparandused, vähem parandatakse interpunktsiooni, minimaalselt morfoloogiat, üldse ei parandata sõnajärge ega vormingut. B1-tasemel parandatakse maksimaalselt endiselt noomenit, aga ka interpunktsiooni, siis ortograafiat, vormingut ja verbi ning endiselt minimaalselt morfoloogiat ja sõnajärge. B2-tasemel tõusevad sagedasimateks interpunktsiooniparandused, noomeniparandused jäävad teisele kohale ja siis tulevad ortograafiaparandused, vähem esineb verbi- ja vorminguparandusi, minimaalselt parandatakse sarnaselt eelnevate tasemetega morfoloogiat ja sõnajärge. C1-tasemel on suurim interpunktsiooniparanduste arv, millele järgnevad noomeniparandused, vähem esineb verbi-, sõnajärje- ja ortograafiaparandusi, minimaalselt parandatakse jälle morfoloogiat ja vormingut. Kokkuvõtvalt võib esile tuua järgmised vormiparanduste suundumused.

1. Kui keeleoskus tõuseb, näitab noomeni-, verbi- ja ortograafiaparanduste vähenemine keelestruktuuri ja reeglite omandamist. Kui 
näiteks noomenit parandatakse sarnase sagedusega A2-ja B1-tasemel, verbi ja ortograafiat B1-ja B2-tasemel, siis C1-tasemel tehakse nimetatud liikides vähem parandusi, seega on märgatav edasiminek, eriti võrreldes A2-tasemega.

2. Keeleoskuse kasvades suureneb interpunktsiooniparanduste hulk kuni B2-tasemeni, mille järel nende arv langeb. Mikrokontekstide analüüs (Pastuhhova 2015: 213) näitas, et keeleoskuse tõusuga muutusid laused pikemaks, seepärast võib interpunktsiooniparanduste arvu kasvu seletada lauseehitusega: parema keeleoskusega kirjutajad kalduvad rohkem lauseid täiendama ning rohkem osalauseid lisama.

3. Kuigi sõnajärjeparandused on minimaalsed ja A2-tasemel neid üldse ei esine, näitavad siinse uurimuse tulemused, et järgmistel tasemetel hakatakse sellele rohkem tähelepanu pöörama: B1-tasemel moodustavad sõnajärjeparandused 2\%, B2-tasemel 3\% ja C1-tasemel koguni $11 \%$ kõigist vormiparandustest. Varem on leitud (Pool \& Vaimann 2006: 210), et venekeelsetel eesti keele õppijatel on sõnajärjevigade valdkond eriti kivinemisaldis, sest vaatamata pidevale korrektiivsele tagasisidele on sõnajärjevead nii kesk- kui ka kõrgtasemel esinemissageduselt esimesel kohal. Siinne kirjutamisprotsessi uurimus näitab, et eesti keele õppijad küll parandavad oma tekstide sõnajärge, edaspidist uurimist vajavad aga küsimused, kas need parandused on õiged või valed ja kui palju vigu vaatamata parandustele ikka tekstidesse sisse jääb.

4. Madalamatel keeleoskustasemetel (A2 ja B1) parandatakse maksimaalselt noomenit, mis lähtub ilmselt reeglite teadvustamisest ja rakendamisest, kõrgematel tasemetel tõuseb tähelepanu keskpunkti (B2 ja C1) interpunktsioon, mis viitab lause moodustajate keerulisemale ehitusele.

5. Noomeni parandused on kõige sagedasemad A2-ja B1-tasemel, kõrgematel tasemetel (B2 ja C1) nende arv väheneb, kuid siiski jäävad need teisele kohale.

6. Morfoloogia-, peamiselt tüvevahelduse parandused on minimaalsed kõigil tasemetel. 
7. Kui iseseisva keelekasutaja B1- ja B2-tasemel on kõigis liikides paranduste keskmised arvud teksti kohta lähedased (v.a noomen ja interpunktsioon), vähenevad vilunud keelekasutaja tasemel kõik vormiparanduste liigid (v.a sõnajärg). Iseseisva keelekasutaja tasemete vormiparandused näitavad keele harjutamist, mis viib keeleomandamiseni ning C1-tase kinnitabki edasiminekut.

Joonis 6 näitab kontseptuaalsete paranduste jaotust.

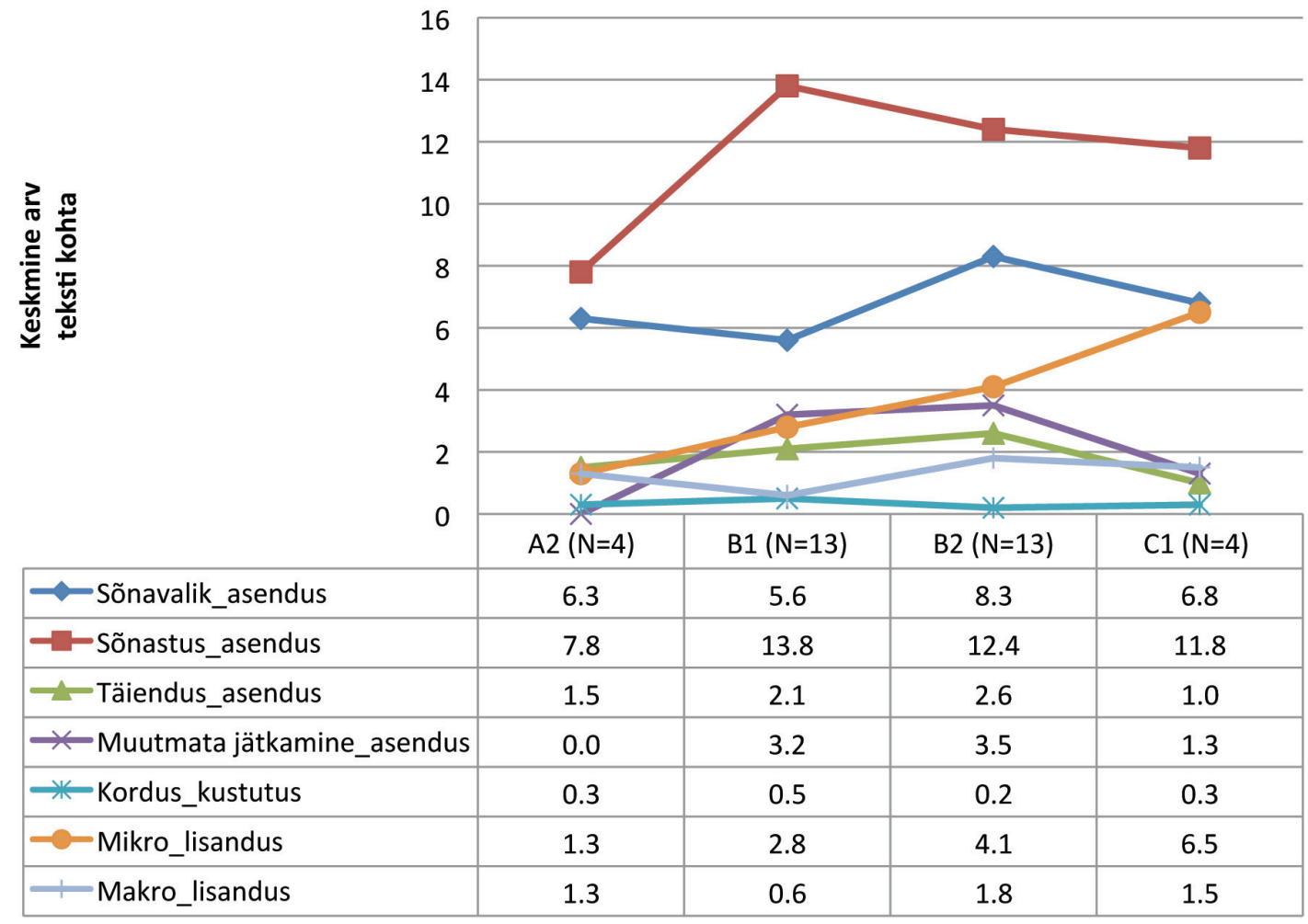

Joonis 6. Kontseptuaalsete paranduste keskmine arv teksti kohta

Joonise põhjal võib esile tuua järgnevad suundumused.

1. Sõnastuse ja sõnavalikuparandused on sagedasimad kõigil tasemetel, kusjuures sõnastuse parandused on maksimaalsed B1-tasemel, kui piiratud keeleoskuse tõttu kogetakse raskusi lause konstrueerimisel ja mõtte edasiandmisel. Alates B2-tasemest parandatakse sõnastust vähem, kuid siiski ületab sõnastuse paranduste arv isegi C1-tasemel A2-taseme paranduste arvu, mis näitab mõtte väljendamise 
komplitseeritust keeleoskusest sõltumata. Pool ja Vaimann (2006: 211) nimetavad sõnavaravigade rohkuse põhjusena ka asjaolu, et keeleoskuse kasvades üritavad keeleõppijad kasutada keerulisemaid väljendeid, mis ei osutu alati õigeks, ning siinse uurimuse loovkirjutistes parandatakse ühe ja sama lause alguse sõnastust sageli mitu korda järjest. Sõnavaliku parandused kõiguvad tasemeti, maksimumi saavutavad need B2-tasemel, mille järel paranduste arv jälle väheneb.

2. Mikrostruktuuri lisandumised on kasvava tendentsiga, kusjuures kõrgematel tasemetel (B2 ja C1) jõuavad nad sõnastuse ja sõnavaliku paranduste järel kolmandale kohale. Keeleoskuse tõustes teksti täiendatakse, üksiksõnu lisatakse varasemasse teksti vilunud keelekasutaja tasemel viis korda rohkem kui esmase keeleoskuse tasemel, mis näitab, et keeleoskuse tõustes produtseeritakse ja töödeldakse teksti üha enam rekursiivselt, mitte lineaarselt.

3. Teksti täiendamise kohta räägib ka kontekstieelselt tehtavate täienduste arv, mis on kasvava tendentsiga kuni B2-tasemeni, mille järel langeb, mis jällegi viitab edasiminekule C1-tasemel, kui teksti produtseeritakse ladusamalt.

4. B1- ja B2-tasemele on omased ka need juhud, kui alustatu kustutatakse, soovides öelda teisiti, kuid mingil põhjusel jätkatakse mõne aja pärast samamoodi, mis jällegi võib viidata sõnavaliku ja sõnastuse probleemidele, millele ei leita lahendust ja seepärast jätkatakse esialgse plaani kohaselt.

5. Makrostruktuuri lisandumiste keskmised arvud on väiksed, kuid siiski on nende arv maksimaalne B2-tasemel. Need on põhjendatavad kirjutajate individuaalsete iseärasustega, sest on omased vähestele uurimuses osalejatele.

6. Minimaalselt kustutatakse kordust, mis tekib eelnevate paranduste tulemusel. 


\subsection{Paranduste jaotus asukoha järgi}

Järgnevalt analüüsitakse kirjutamisprotsessi muudatusi vastavalt asukohale: kui parandus esines mõtte väljendamise hetkel seni kirjutatud viimase sõna/tähemärgi lõpus, on tegemist kontekstieelse parandusega, kui muudatus tehti varasemas tekstis ehk kontekstis, on tegu kontekstisidusa parandusega. Võrreldakse kontekstieelseid ja -sidusaid parandusi jaotatuna trükivigadeks, vormi-, kontseptuaalseteks parandusteks ning arusaamatute muudatuste puhul määratlemata kategooriaks.

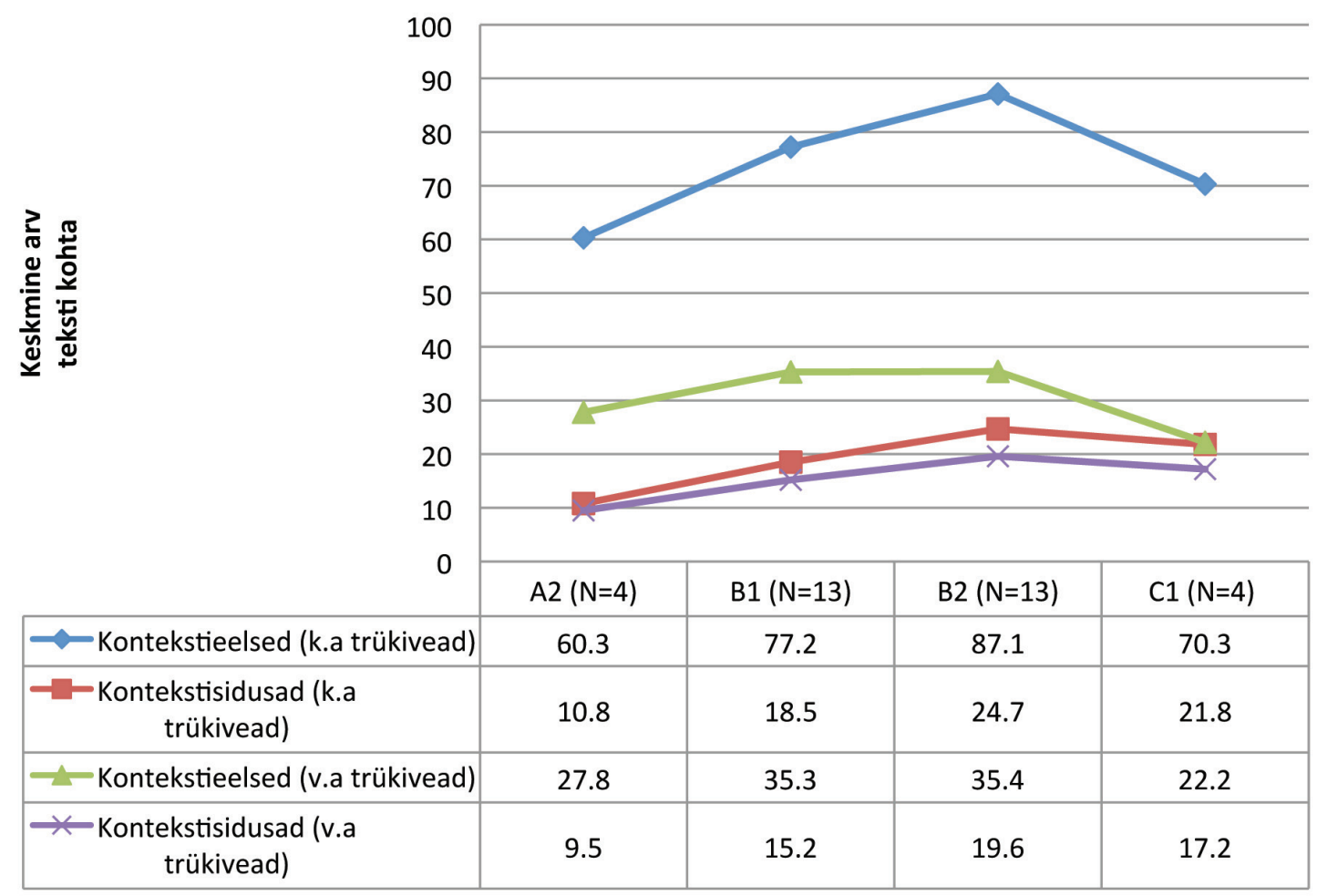

JoonIs 7. Paranduste jaotus asukoha järgi

Kui eristada kontekstieelseid ja kontekstisidusaid parandusi, siis joonisest 7 järeldub, et mõtte väljendamise hetkel tehakse palju rohkem parandusi kui varasemasse teksti, mis kinnitab Stevensoni jt (2006: 218) tulemust.

Sarnaselt paranduste üldise tendentsiga suurenevad nii kontekstieelsed kui ka -sidusad parandused kuni B2-tasemeni, mille järel nende arv langeb. 
Kui Stevenson jt (2006: 218) leidsid, et varasemat teksti muudetakse äärmiselt harva, siis siinne uurimus seostab kontekstisidusate paranduste kasvu keeleoskustasemega. Tabelis 5 on esitatud kontekstieelsete ja -sidusate paranduste osakaal iga taseme raames ja selle jaotuse protsentuaalne muutus keeleoskustasemeti.

TABEL 5. Kontekstieelsete ja kontekstisidusate paranduste (k.a ja v.a trükivead) osakaal

\begin{tabular}{|l|c|c|c|c|c|c|c|c|}
\hline & \multicolumn{2}{|c|}{ A2 (N) } & \multicolumn{2}{c|}{ B1 (N) } & \multicolumn{2}{c|}{ B2 (N 13) } & \multicolumn{2}{c|}{ C1 (N = 4) } \\
\cline { 2 - 9 } & k.a tr & v.a tr & k.a tr & v.a tr & k.a tr & v.a tr & k.a tr & v.a tr \\
\hline Kontekstieelsed & $85 \%$ & $75 \%$ & $81 \%$ & $70 \%$ & $78 \%$ & $64 \%$ & $76 \%$ & $56 \%$ \\
\hline Kontekstisidusad & $15 \%$ & $25 \%$ & $19 \%$ & $30 \%$ & $22 \%$ & $36 \%$ & $24 \%$ & $44 \%$ \\
\hline
\end{tabular}

Tabel illustreerib keeleoskuse tõusuga kaasnevat kontekstieelsete paranduste vähenemist ning kontekstisidusate paranduste suurenemist, mis tähendab, et mida kõrgem on keeleoskus, seda rohkem loetakse varasemat teksti üle ning muudetakse seda. Keeleoskuse tõustes tuleb kontekstieelne tekst korrektsem välja ja kirjutamine muutub ladusamaks, nii et keskendutakse rohkem sisu edasiandmisele, jättes osa vigu kontekstisidusaks parandamiseks ja täiendamiseks.

Kui võrrelda, kuidas jaotuvad kontekstieelsed ja kontekstisidusad parandused liigiti, siis kontekstieelsete paranduste jaotus (vt joonis 8) sarnaneb paranduste jaotusega tervikuna. Kõige rohkem parandatakse mõtte väljendamise hetkel trükivigu, millele järgnevad kontseptuaalsed ja alles siis vormiparandused, seega ei osutu uurimuse teine hüpotees õigeks. Vormiparandusi on küll maksimaalselt A2-tasemel, mille järel keeleoskuse paranedes need aina vähenevad, kontseptuaalseid parandusi on vastupidi minimaalselt madalaimal tasemel ja maksimaalselt B1-ja B2-tasemel, kuid siiski ületavad nad kõigil tasemetel vormimuudatuste arvu.

Erinevalt kontekstieelsetest parandustest märgatakse ja parandatakse madalamatel tasemetel (A2 ja B1) kontekstisidusalt (vt joonis 9) kõige rohkem grammatikat, kuigi vormiparanduste arv on kontekstieelsete vormiparandustega võrreldes väiksem. 


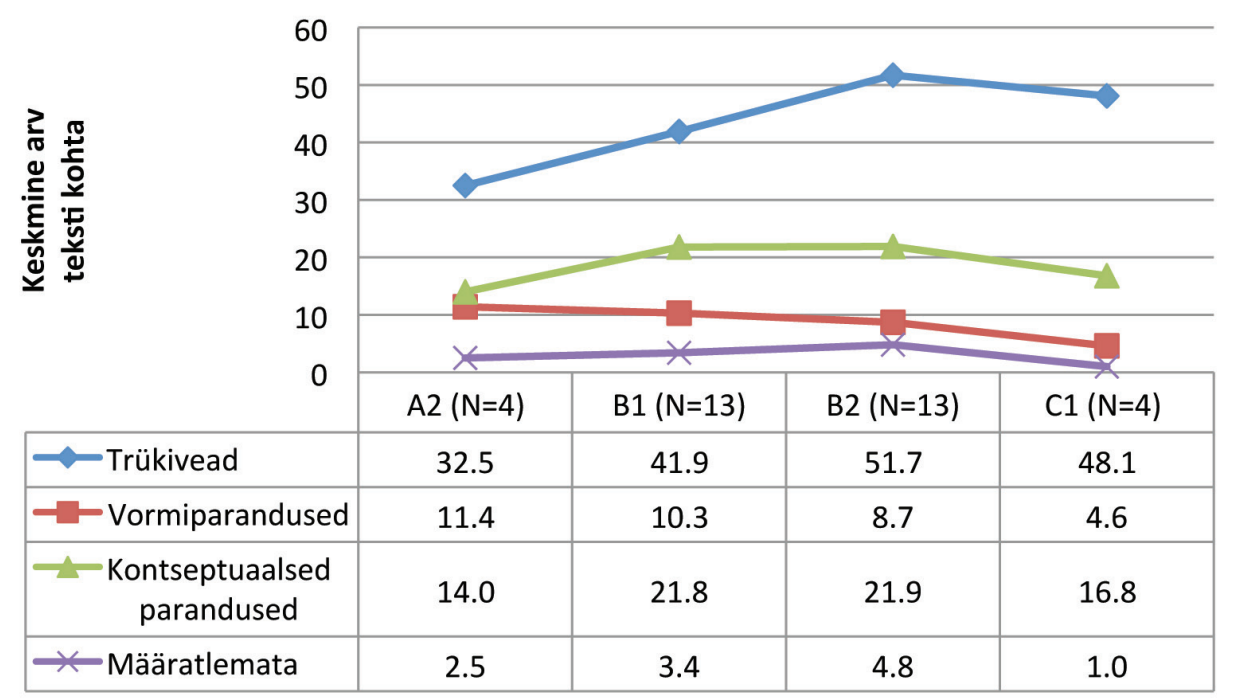

Joonis 8. Kontekstieelsete paranduste keskmine arv teksti kohta

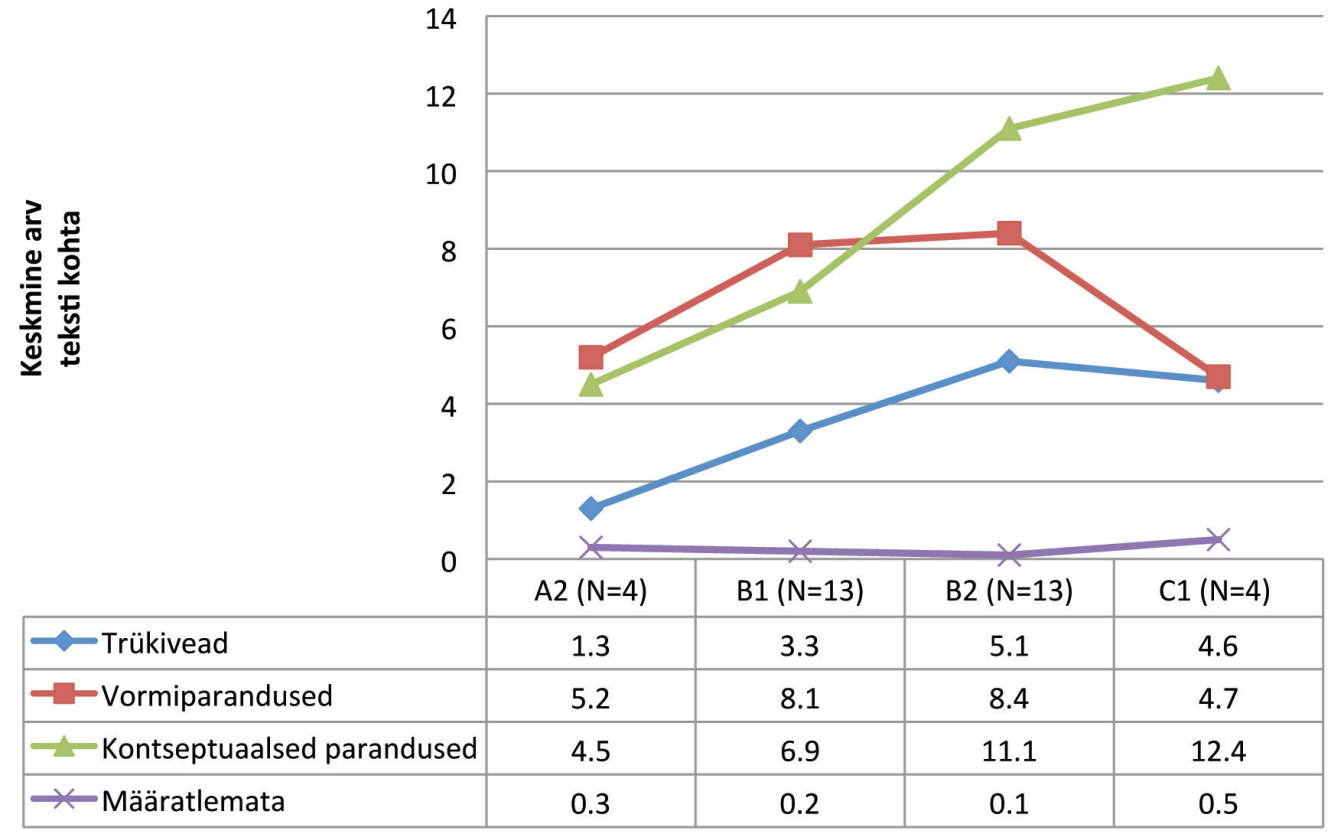

Joonis 9. Kontekstisidusate paranduste keskmine arv teksti kohta

Juba kirjutatud teksti läbilugemisel suurenevad vormiparandused B2-tasemeni, mille järel need vähenevad. Varasema teksti kontseptuaalsed parandused on erinevalt kontekstieelsetest keeleoskustasemeti suureneva tendentsiga. Kui madalamatel keeleoskustasemetel (A2 ja B1) märgatakse ja parandatakse varasemas tekstis maksimaalselt vormi, 
siis kõrgematel tasemetel (B2 ja C1) keskendutakse maksimaalselt sisu parandamisele, see erinevus on eriti ilmne C1-tasemel. Seega on põhierinevus kontekstieelsete ja kontekstisidusate paranduste vahel (kui trükivead välja arvata) selles, et teksti kirjutamisel kontekstieelselt keskendutakse kõigil tasemetel keeleoskusest sõltumata esiteks sisu edasiandmisele ja mõtte sõnastamisele ja siis vormile. Kui aga juba kirjutatud teksti läbi loetakse, siis madalamatel tasemetel (A2 ja B1) märgatakse ja parandatakse rohkem grammatikat, kõrgematel tasemetel (B2 ja C1) jääb prioriteediks teksti kontseptuaalne pool, millele järgneb vorm. Muidugi on see seletatav ka sellega, et suurenenud keeleoskusega kirjutajatel on grammatika selgem ning vormivigu on vähem, nii et prioriteediks jääbki teksti sisu.

Kontekstieelsete ja -sidusate vormi- ja kontseptuaalsete paranduste täpsemat jaotust siinses uurimuses eraldi ei kirjeldata. Vormiparandused mõlema asukoha järgi on üldjoontes sarnased vormiparandustega tervikuna. Täpseid arvandmeid ega suundumusi ei ole mõttekas eraldi välja tuua vormiparanduste, eriti kontekstisidusate paranduste vähesuse tõttu. Aga kui võrrelda kontekstieelsete ja kontekstisidusate kontseptuaalsete paranduste jaotust, siis mõtte väljendamise hetkel on kõigil tasemetel sagedasemad sõnastuse ja sõnavaliku parandused, kui aga tekst on juba produtseeritud ja seda loetakse üle, siis lisatakse kõige rohkem üksiksõnu, kusjuures mida parem on keeleoskus, seda rohkem püütakse teksti lokaalselt täiendada.

\subsection{Paranduste jaotus valdkonna järgi}

Lõpetuseks esitatakse parandused vastavalt sellele, millist teksti hulka muudatus hõlmas: kas sõna tervikuna või sõna osa, kas lause osa ning kas tervet lauset või pikemat teksti. Joonis 10 illustreerib paranduste keskmist arvu teksti kohta valdkonna järgi. 


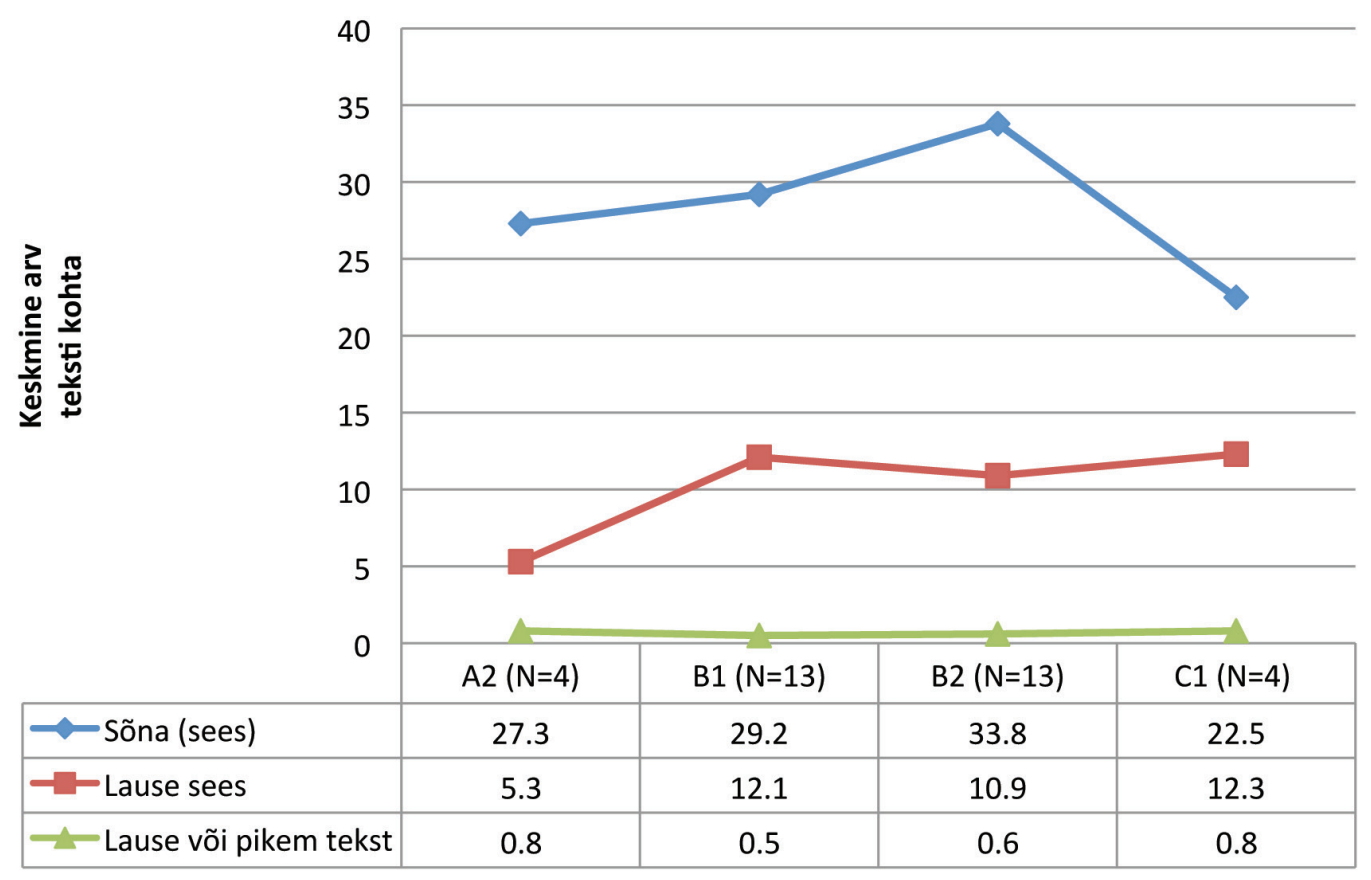

Joonis 10. Paranduste jaotus valdkonna järgi

Kõige rohkem muudetakse sõna või sõna osa, millele järgnevad parandused lause sees ja väikese osa moodustavad lause või pikema teksti muudatused - tulemus, mis kinnitab Stevensoni jt (2006: 215) oma. Pikema teksti parandused on omased vähestele uurimuses osalejatele, siit tuleneb nende väike keskmine arv. Üksikud osalejad on suutnud oma tähelepanu keskendada pikemale tekstile korraga, muutes ja lisades koguni lõike.

\section{Kokkuvõte}

Artikli eesmärk oli kirjeldada multidimensionaalse taksonoomia abil venekeelsete eesti keele õppijate kirjutamisprotsessi paranduste seisukohast ning seostada tehtavad parandused keeleoskustasemega. Tulemused näitavad, et teksti kirjutamist igal keeleoskustasemel iseloomustab suur paranduste hulk, mis saavutab maksimumi iseseisva keelekasutaja edasijõudnu tasemel. Just B2-taseme teksti rohke parandamine näitab keeleoskuse edasiminekut, mida kinnitab paranduste vähenemine 
C1-tasemel. Keeleoskuse tõusuga pööratakse rohkem tähelepanu teksti kustutamisjärgsete paranduste kõrval teksti täiendamisele ja lisandumistele. Kõigil tasemetel valmistab kirjutajatele raskust esiteks sisu edasiandmine ja mõtete sõnastamine, millele järgneb õige vormi valik, kusjuures kui A2-tasemel on kirjutaja fookus peaaegu võrdselt suunatud nii vormi kui ka sisu parandamisele, keskendub kirjutaja keeleoskuse tõustes kõigepealt teksti sisule. Vormimuudatustest paistab silma noomeniparanduste vähenemine alates B2-tasemest ja interpunktsiooniparanduste kasv A2-tasemest kuni B2-tasemeni, mis näitab ühelt poolt grammatiliste teadmiste omandamist ja teiselt poolt keerulisemat lauseehitust keeleoskuse tõustes. Kui iseseisva keelekasutaja tasemetel parandatakse vormi sarnase sagedusega (v.a noomen ja interpunktsioon), siis C1-tasemele on omane vormiparanduste langus, mis kinnitab keeleomandamise edasiminekut. Kontseptuaalsetest parandustest valmistab keeleoskusest sõltumata enim raskusi sõnavara. Kontekstieelseid ja -sidusaid parandusi eristab kõigil tasemetel sisu edasiandmisele suunatud fookus, kontekstisidusalt pööratakse madalamatel tasemetel rohkem tähelepanu vormile, kõrgematel tasemetel sisule. Kui käesolevas uurimuses on vaadeldud kirjutamisprotsessi muudatusi kirjutajate seisukohast, vajab edaspidist uurimist kirjutamisprotsessi jooksul tehtud paranduste võrdlus lõpliku teksti kvaliteediga, saamaks selgust, kas teksti rohke parandamine kirjutaja poolt viib korrektse lópliku produktini ning mille poolest erinevad protsessi parandused ja lóplikku teksti jäänud vead.

\section{Kirjandus}

Alamargot, Denis, Lucile Chanquoy 2001. Revising process. - Gert Rijlaarsdam (Series ed.), Denis Alamargot, Lucile Chanquoy. Studies in Writing 9. Through the Models of Writing. Dordrecht-Boston-London: Kluwer Academic Publishers, 99-123.

Baaijen, Veerle M. 2012. The Development of Understanding Through Writing. Groningen Dissertations in Linguistics 107.

Baaijen, Veerle M., David Galbraith, Kees de Glopper 2012. Keystroke analysis: reflections on procedures and measures. - Written Communication 29 (3), 246-277. http://dx.doi.org/10.1177/0741088312451108 
Becker, Anne 2006. A review of writing model research based on cognitive processes. - Alice Horning, Anne Becker (Eds.), Revision: History, Theory, and Practice. Parlor Press, The WAC Clearinghouse, 25-49.

Breuer, Esther Odilia 2014. First Language versus Foreign Language. Fluency, Errors and Revision Processes in Foreihn Language Academic Writing. Inaugural Dissertation zur Erlangung der Doktorwürde der Philosophischen Fakultät der Rheinischen Friedrich Wilhelms Universität zu Bonn. http://hss.ulb. uni-bonn.de/2014/3480/3480.pdf

Chenoweth, N. Ann, John R. Hayes 2001. Fluency in writing: generating text in L1 and L2. - Written Communication 18 (1), 80-98. http://dx.doi.org/10.1177 /0741088301018001004

Euroopa keeleõppe raamdokument: õppimine, õpetamine ja hindamine. Tõlkijad Ülle Türk, Krista Kerge ja Mai Tiits; toimetajad Helika Mäekivi, Pilvi Alp, Hille Pajupuu, Mai Tiits, Ülle Türk. Tartu: Haridus- ja Teadusministeerium, 2007.

Faigley, Lester, Stephen Witte 1981. Analysing revision. - College Composition and Communication 32 (4), 400-414. http://dx.doi.org/10.2307/356602

Fitzgerald, Jill 1987. Research on revision in writing. - Review of Educational Research 57 (4), 481-506. http://dx.doi.org/10.3102/00346543057004481

Flower, Linda, John R. Hayes 1981. A cognitive process theory of writing. - College Composition and Communication 32 (4), 365-387. http://dx.doi. org/10.2307/356600

Galbraith, David 2009. Cognitive models of writing. - GFL Journal 2-3, 6-22.

Gustilo, Leah, Carlo Magno 2015. Explaining L2 writing performance through a chain of predictors: A SEM approach. - The Southeast Asian Journal of English Language Studies 21 (2), 115-130. http://dx.doi. org/10.17576/3L-2015-2102-09

Hayes, John R. 1996. A new framework for understanding cognition and affect in writing. - C. Michael Levy, Sarah Ransdell (Eds.), The Science of Writing: Theories, Methods, Individual Differences, and Applications. Lawrence Erbaum Associates, 1-27.

Hayes, John R. 2004. What triggers revision? - Linda Allal, Lucile Chanquoy, Pierre Largy (Eds.), Revision: Cognitive and Instructional Processes. Springer Science+Business Media, 9-20.

Hayes, John R. 2012. Modeling and remodeling writing. - Written Communication 29 (3), 369-388. http://dx.doi.org/10.1177/0741088312451260

Hayes, John R., Linda Flower 1980. Identifying the organization of writing processes. - L. W. Gregg, E. R. Steinberg (Eds.), Cognitive processes in Writing. Hillsdale, NJ: Erlbaum, 3-30. 
Hayes, John R., Linda Flower, Karen A. Schriver, James F. Stratman, Linda Carey 1987. Cognitive processes in revision. - S. Rosenberg (Ed.), Reading, Writing, and Language Processes. Cambridge: Cambridge University Press, 176-240.

Khuder, Baraa, Nigel Harwood 2015. L2 writing in test and non-test situations: process and product. - Journal of Writing Research 6 (3), 233-278. http:// dx.doi.org/10.17239/jowr-2015.06.03.2

Leijten, Mariëlle, Luuk Van Waes, Sarah Ransdell 2010. Correcting text production errors: Isolating the effects of writing mode from error span, input mode, and lexicality. - Written Communication 27 (2), 198-227. http:// dx.doi.org/10.1177/0741088309359139

Lindgren, Eva, Kirk P. H. Sullivan 2006a. Writing and the analysis of revision: an overview. - Kirk P. H. Sullivan, Eva Lindgren (Eds.), Computer Keystroke Logging and Writing: Methods and Applications. Oxford: Elsevier, 31-44.

Lindgren, Eva, Kirk P. H. Sullivan 2006b. Analysing online revision. - Kirk P. H. Sullivan, Eva Lindgren (Eds.), Computer Keystroke Logging and Writing: Methods and Applications. Oxford: Elsevier, 157-188.

Nordqvist Palviainen, Åsa 2007. What is beneath the surface? Comparing the product and process of L2 texts written by university students. - O.-P. Salo, T. Nikula, P. Kalaja (Toim.), Kieli oppimisessa - Language in Learning. AfinLA:n vuosikirja. Suomen soveltavan kielitieteen yhdistyksen julkaisuja 65, 233-249.

Palviainen, Åsa, Paula Kalaja, Katja Mäntylä 2012. Development of L2 writing: Fluency and proficiency. - L. Meriläinen, L. Kolehmainen, T. Nieminen (Toim.), AFinLA-e Soveltavan kielitieteen tutkimuksia 4, 47-59.

Pastuhhova, Olga 2015. Using micro-contexts to describe a writing process in Estonian as a second language across proficiency levels. - Eesti Rakenduslingvistika Ühingu aastaraamat 11, 205-222. http://dx.doi.org/10.5128/ ERYa11.13

Pool, Raili, Elle Vaimann 2005. Vead kõrgtasemel eesti keele kõnelejate kirjalikus keelekasutuses ['Errors in written Estonian by advanced level speakers']. Eesti Rakenduslingvistika Ühingu aastaraamat 1, 115-137. http://dx.doi. org/10.5128/ERYa1.06

Pool, Raili, Elle Vaimann 2006. Kivinemisnähtusi vene üliõpilaste kirjalikus eesti keeles ['Evidence of fossilization in the written Estonian language of Russian students']. - Eesti Rakenduslingvistika Ühingu aastaraamat 2, 203217. http://dx.doi.org/10.5128/ERYa2.14

Schoonen, Rob, Patrick Snellings, Marie Stevenson, Amos Van Gelderen 2009. Towards a blueprint of the foreign language writer: The linguistic and 
cognitive demands of foreign language writing. - R. M. Manchón (Ed.), Writing in Foreign Language Contexts. Learning, Teaching, and Research. Bristol: Multilingual Matters, 77-101.

Silva, Tony 1993. Towards an understanding of the distinct nature of L2 writing: The ESL research and its implications. - TESOL Quarterly 27 (4), 657-677. http://dx.doi.org/10.2307/3587400

Spelman Miller, Kristyan, Eva Lindgren, Kirk P. H. Sullivan 2008. The psycholinguistic dimension in second language writing: opportunities for research and pedagogy using computer keystroke logging. - TESOL Quarterly 42 (3), 433-451. http://dx.doi.org/10.1002/j.1545-7249.2008.tb00140.x

Stevenson, Marie, Rob Schoonen, Kees de Glopper 2006. Revising in two languages: A multi dimensional comparison of online writing revisions in L1 and FL. - Journal of Second Language Writing 15 (3), 201-233. http://dx.doi. $\operatorname{org} / 10.1016 /$ j.jslw.2006.06.002

Thorson, Helga 2000. Using the computer to compare foreign and native language writing processes: A statistical and case study approach. - The Modern Language Journal 84 (2), 155-170. http://dx.doi.org/10.1111/0026-7902.00059

Van Gelderen, Amos, R. Oostdam 2004. Revisions of form and meaning in learning to write comprehensible text. - Gert Rijlaarsdam (Series Ed.), Linda Allal, Lucile Chanquoy, Pierre Largy (Vol. Eds.), Studies in Writing 13. Revision: Cognitive and Instructional Processes. Dordrecht: Kluwer Academic Publishers, 103-124.

Verschik, Anna 2004. Mõnda vahekeelest ja kontrastiivsest analüüsist. - Mart Rannut (koost.), Mart Rannut, Marju Kõivupuu, Tiit Päeva (toim.), Eesti keel: võõrkeelest teiseks keeleks. Tallinna Pedagoogikaülikooli eesti filoloogia osakonna toimetised 1. Tallinn: TPÜ Kirjastus, 132-144. 


\title{
Multi-dimensional comparison of revisions across proficiency levels in the writing process of learners of L2 Estonian
}

\author{
OLGA PASTUHHOVA \\ Tallinn University
}

Revision is an integral part of the writing process according to John R. Hayes and Linda S. Flower's (1980; Flower \& Hayes 1981; Hayes et al. 1987; Chenoweth \& Hayes 2001; Hayes 2012) writing model. The model incorporates the nature of revision, its function and the cognitive processes involved. The writing process can also be analysed according to revision taxonomies created as a methodological tool to assist researchers in their study of revision. Writing process models show the reasons behind revisions, whereas taxonomies reflect the impact of revision on the written text.

The current article presents an overview of writing process revisions according to the writing model and focuses on the revisions made by native Russian-speaking learners of Estonian as a second language (L2) based on a multi-dimensional revision taxonomy (Stevenson et al. 2006) as well as the taxonomy of Eva Lindgren and Kirk P. H. Sullivan (2006b). While earlier research has focused on comparison of revisions made in first and second/foreign language writing, the present study aims to describe revisions made in the writing of native Russian-speaking learners of Estonian as an L2, across A2, B1, B2 and $\mathrm{C} 1$ proficiency levels of the Common European Framework of Reference for Languages (CEFR).

Text produced by 34 participants provided the source of the study's data, which were collected with the computer keystroke logging program ScriptLog. The written texts were rated by two experts as belonging to the following CEFR levels: A2 (4 texts), B1 (13), B2 (13), and C1 (4). The online revisions were analysed by action (substitutions and additions), orientation (typing, form and conceptual revisions), location (pre-contextual and contextual revisions) and domain (below-word, below-clause, clause and above), and further compared across the proficiency levels. 
The results show that writing across all proficiency levels is characterised by a large number of revisions, with B2 level having the greatest number. The great number of revisions at B2 level demonstrates progress in proficiency, as evidenced by a decrease in revisions at $\mathrm{C} 1$ level. As language proficiency increases, more attention is paid to text supplementation, and additions alongside substitutions followed deletions. Across all proficiency levels the learners face difficulty first in formulating content and then in producing the appropriate form, whereas at A2 level the learner focuses almost equally on conceptual and form revisions; with growth in proficiency conceptual revisions become dominant.

Keywords: second language acquisition; writing proficiency; computer keystroke logging; ScriptLog; multidimensional taxonomy; LS-taxonomy; Estonian; Russian

\section{Olga Pastuhhova}

Tallinna Ülikool, humanitaarteaduste instituut

Narva mnt 29

10120 Tallinn, Estonia

olga.pastuhhova@tlu.ee 